\title{
PERCURSOS DE ESCOLARIZAÇÃO E TRABALHO DOCENTE DE MULHERES PESQUISADORAS
}

\author{
Paulo Sérgio de Almeida Corrêa \\ Universidade Federal do Pará \\ Instituto de Ciências da Educação \\ Programa de Pós-Graduação em Educação \\ Faculdade de Educação \\ paulosac@ufpa.br
}

\section{RESUMO}

Buscou-se compreender as trajetórias de escolarização e o trabalho docente de mulheres envolvidas com a atividade de pesquisa no campo da educação, a fim de entender seu preparo acadêmico, a inserção e atuação nos grupos de pesquisa, as temáticas que entrecortam seus objetos de pesquisa, assim como os tipos de veículos adotados para fazer circular os produtos científicos. Como se prepararam academicamente as mulheres que se projetaram com o perfil de pesquisadoras no campo da educação? Como se configura sua participação nos grupos de pesquisa? Em quais tipos de veículos circulam suas produções acadêmicas? Quais as temáticas que permeiam os objetos de estudos de suas investigações? Incidiu nos Programas de Pós-Graduação da área de Educação da Região Norte do Brasil, mediante consulta a Plataforma Lattes (http://www.cnpq.br), às Sínteses de Indicadores dos Programas (http://www.capes.gov.br), e à literatura sobre a trajetória de formação e o trabalho docente (http://www.anped.org.br). Os grupos de pesquisa impulsionaram as equipes de trabalho, fomentaram a pesquisa, redesenharam o espaço institucional, elevaram a produção de conhecimento na área de educação, ampliaram o acesso a recursos financeiros, e o intercâmbio acadêmico-científico interinstitucional.

Palavras-Chave: Escolarização de Mulheres; Trabalho Docente; Pesquisa.

\section{PATHWAY OF EDUCATION AND TEACHING WORK OF WOMEN RESEARCHERS}

\begin{abstract}
We sought to understand the trajectories of education and teaching work of women involved with the research activity in education, in order to understand their academic preparation, integration and performance in research groups, the themes that intersect research subjects, and the types of vehicles adopted to circulate scientific products. How prepared academically women who were projected to the profile of researchers in the field of education? How to setup your participation in the research groups? In what types of vehicles circulate their academic production? What are the themes that permeate the objects of their research studies? Programs focused on Postgraduate in the area of Education of the North of Brazil, in consultation with the Lattes Platform (http://www.cnpq.br), Summaries of the Indicators Program ((http://www.capes.gov.br), and the literature on career training and teaching (http://www.anped.org.br). The research groups pushed work teams to foster the research, redesigned the institutional space, increased the production of knowledge in education, increased access to financial resources, academic exchange and scientific and institutional.
\end{abstract}

Keywords: Education of Women; Teaching Work; Research. 


\section{Introdução}

Pesquisa desenvolvida para apresentação na Comunicação Coordenada 3 - História da Educação de Mulheres, da qual participaram além de mim, os professores Clarice Nascimento de Melo (UFPA); Celita Maria Paes de Sousa (UFPA). A programação integrou o I Colóquio de História da Educação do Pará: o estado do conhecimento em História da Educação no Pará, realizado em Belém (Instituto de Ciências Jurídicas e Instituto de Ciências da Educação da Universidade Federal do Pará), no período de 29 e 30 de novembro do ano de 2011, com as seguintes pretensões: Promover a articulação e integração de pesquisadores em história da educação do Pará, de modo a sedimentar a produção já existente, estimulando novas parcerias e novos estudos; Divulgar os resultados das pesquisas produzidas nos últimos anos; Divulgar os resultados de pesquisas produzidas; Estimular a formação de novos pesquisadores.

A finalidade da pesquisa consistiu em compreender as trajetórias de escolarização e o trabalho docente de mulheres envolvidas com a atividade de pesquisa no campo da educação, a fim de entender seu preparo acadêmico, a inserção e atuação nos grupos de pesquisa, as temáticas que entrecortam seus objetos de pesquisa, assim como os tipos de veículos adotados para fazer circular os produtos científicos.

Os estudos sobre escolarização e trabalho docente sofreram significativa ampliação no contexto educacional brasileiro. São provenientes das dissertações de mestrado e teses de doutorado parcelas dessa contribuição, evidenciando a importância assumida pelos Programas de Pós-Graduação em Educação instalados em diferentes instituições educativas, quando se trata da produção do conhecimento científico.

Contudo, os níveis de escolarização da Educação Básica se converteram em espaços prioritários dos investimentos realizados pelos pesquisadores, sobressaindo o interesse pelos cursos de licenciatura, pedagogia, a escola normal e os institutos de educação. Porém, existem trabalhos cujos autores se dedicaram a inspecionar os percursos de formação e atuação dos pesquisadores em diversos níveis, particularmente na educação superior.

Pesquisas como aquelas desenvolvidas por Alves e Cunha (2011), Campos (2011), Costa Junior (2011), Isaia, Maciel e Bolzan (2010), Maciel, Rocha, Isaia e Bolzan (2009), Mury (2011), Oliveira (2011), Powaczuk e Bolzan (2011), Rosa (2011), analisaram a docência universitária, seja pelo viés da política de avaliação da pós-graduação, a formação, produção científica, sua profissionalização, ou a trajetória na docência.

Neste estudo, portanto, a centralidade das análises estará nos percursos de escolarização, bem como no exercício do trabalho docente empreendido por mulheres que se constituíram pesquisadoras na área de educação.

Sob essa perspectiva, foram concebidos os seguintes problemas de pesquisa: Como se prepararam academicamente as mulheres que se projetaram com o perfil de pesquisadoras no campo da educação? Como se configura sua participação nos grupos de pesquisa? Em quais tipos de veículos circulam suas produções acadêmicas? Quais as temáticas que permeiam os objetos de estudos de suas investigações?

A investigação teve como local de incidência a grande área de Ciências Humanas, onde estão distribuídos os Programas de Pós-Graduação da área de Educação da Região Norte do Brasil, situados na Universidade Federal do Pará, Universidade Federal do Amazonas, Universidade Federal de Roraima e Universidade do Estado do Pará. Esses Programas são recomendados pela CAPES e na última avaliação trienal receberam notas entre 3 e 4. Portanto, a amostra incidiu nas universidades públicas, das quais três são federais e uma estadual.

Foram escolhidas quatro docentes pesquisadoras, dando-se prioridade ao grupo com maior tempo de obtenção da titulação acadêmica no nível do doutorado, chegando-se aos seguintes sujeitos, segundo a instituição na qual atualmente exercem a docência na PósGraduação: UFAM: Rosa Mendonça de Brito; UFPA: Olgaíses Cabral Maués; UNIR: Tânia Suely Azevedo Brasileiro; UEPA: Elizabeth Teixeira ${ }^{1}$. 


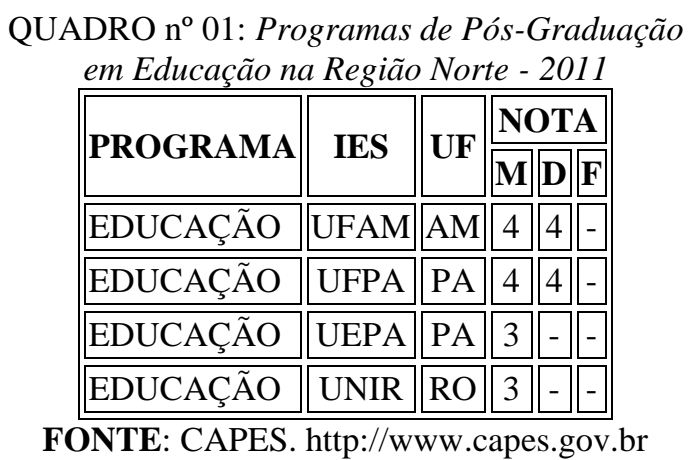

Analisei as trajetórias de escolarização de mulheres pesquisadoras a partir da formação obtida no nível superior, de modo a perceber o protagonismo por elas exercido quando da liderança e/ou participação em grupos de pesquisa, a circulação da produção científica, bem como as temáticas em que se circunscrevem os objetos de estudos das investigações que realizam.

A produção dos indicadores contou com o apoio da internet, cujo recurso tecnológico tornou possível acessar referências sobre os sujeitos docentes implicados neste estudo, sendo essencial a consulta realizada na Plataforma Lattes localizada na Base de Dados do Conselho Nacional de Desenvolvimento Científico Tecnológico - CNPq http://www.cnpq.br, bem como as Sínteses de Indicadores dos Programas de Pós-Graduação em Educação da Região Norte, extraídas no endereço http://www.capes.gov.br.

O desenvolvimento das reflexões teve suporte na literatura especializada em que seus autores localizam a trajetória de formação e o trabalho docente como objeto de investigação. Assim, os textos foram catalogados nos Grupos de Trabalho 08, 11 e 12, que tratam respectivamente, da Formação de Professores, Estado e Política da Educação Superior, e Currículo, pertencentes às Reuniões Anuais realizadas pela Associação de PósGraduação e Pesquisa em Educação - ANPED, extraídos de sua página virtual http://www.anped.org.br.

Ao todo houve acesso e consulta a nove trabalhos, os quais se distribuíram nos Grupos de Trabalho da seguinte forma: 07 autores enviaram os resultados de suas pesquisas para o GT $08(77,77 \%)$, enquanto os GTs $11(11,11 \%)$ e $12(11,11 \%)$ contaram com 01 representante cada.

Igualmente importante foi o estudo do Currículo Lattes de cada autor acionado como sujeito da pesquisa, uma vez que nesse suporte cultural encontramos parte dos vestígios registrados na base eletrônica de dados, com ênfase nas seguintes dimensões: formação acadêmica; participação em grupos de pesquisa; as produções científicas; e os objetos de estudos privilegiados. Com essa intencionalidade, considerou-se a última data de atualização realizada pelos docentes pesquisadores no ano de 2011.

Quanto ao tempo de abrangência da pesquisa, considerou-se para efeito da construção analítica dos percursos de escolarização e do trabalho docente o ano de 1969, o qual representa a conclusão no curso de graduação de um dos sujeitos, tendo seu termo final no ano de 2011, considerando-se a data da última atualização das informações registradas no Currículo Lates dos professores selecionados para estudo.

Portanto, os sujeitos escolhidos exercem a docência no ensino de graduação e pósgraduação, têm passagem na administração, participam ou lideram grupos de pesquisa, apresentam produtividade científica difundida por diversos veículos de circulação. 


\section{A formação acadêmica das mulheres pesquisadoras no campo da educação}

Alves e Cunha (2011, p.1) discutiram a atividade humana sob o ponto de vista dos saberes, valores e trabalho docente. Dedicaram-se à análise acerca das "abordagens do campo de estudos sobre os saberes dos professores e sinaliza contribuições que a noção de atividade pode trazer aos interessados em compreender o âmbito do trabalho dos professores e nele intervir". Perceberam que tais abordagens são capazes de "agregar inovadoras formas de produção de conhecimento e de intervenção às pesquisas em educação que se interessam pelos professores, por seu trabalho e por seus saberes". Admitem que "a atividade é a ferramenta heurística e a unidade que guarda uma problemática sempre a interrogar as situações de trabalho e seus sujeitos". Contudo, fazem uma advertência:

Incorporar o trabalho como atividade humana em nossas análises tem implicações epistemológicas muito sérias, posto que, além de fazer a análise da atividade tal como nos propõe a ergonomia, esse triângulo ergológico saberes-valores-atividade exige extrair consequências para o terreno da produção científica nos diversos campos do saber que estudam o trabalho humano, para o campo das ciências humanas em geral e para compreender aspectos subjetivos que permeiam a produção científica (ALVES e CUNHA, Op. Cit., p.8).

Além disso, desvelam o fato de que a atividade humana se encontra permeada por normas prefixadas, mas, mesclam-se a elas valores imprevistos quando de seu funcionamento, conforme se manifestam:

Toda atividade pode ser analisada pelas normas produtivas dimensionadas na tarefa; entretanto, as atividades humanas agem também orientadas por valores sem dimensão, os valores do bem comum, por exemplo. E agem numa relação com as normas de produção de um ponto de vista que é singular, pois construído nas vivências de trabalho e vida do trabalhador e nos projetos herdados de coletivos os quais integrou (ALVES e CUNHA, Idem., p. 10).

Embora os saberes e valores não se constituam objeto de reflexão de minha pesquisa na construção do presente texto, a noção de atividade humana auxilia na percepção de que, também, as pesquisadoras da área de educação se constroem em meio a uma intrigada rede de situações oriundas das esferas institucionais, porém, não ficam reféns dessa normatividade, uma vez que durante sua prática científica, mobilizam saberes e constroem e fazem circular valores igualmente diferenciados sobre situações diversas por elas protagonizadas.

Maciel, Isaia e Bolzan (2009, p. 2) refletiram sobre as trajetórias de formação de professores universitários com ênfase no estudo da ambiência docente, considerando esta como "uma configuração resultante do impacto das condições externas de trabalho sobre o mundo interior dos docentes, agindo como força gerativa ou restritiva no processo de transformação em direção ao bem-estar e auto-realização profissional". Sendo definida como "um conjunto de forças ambientais objetivas (externas), subjetivas (intrapessoais) e intersubjetivas (interpessoais)", e nesse contexto as "repercussões no processo de desenvolvimento do profissional, podem permitir ou restringir a [re] significação das experiências ao longo da vida e da carreira e, conseqüentemente, da trajetória formativa".

No entendimento de Maciel, Isaia e Bolzan (Op. Cit., p. 6) o sujeito docente em seu percurso de vida pessoal e profissional se produz em múltiplos contextos, pois, conforme afirmam as autoras, 
Sabemos que a experiência humana vai sendo construída/reconstruída nos diferentes contextos. Nesse processo, a trajetória vai adquirindo significados nos sentimentos e cognições, expressando-se na produção dos saberes e no agir intencional que torna o docente partícipe também da história da profissão e da instituição.

Assim, a dinâmica apresentada pela instituição pode interferir na esfera profissional, evidenciando o quanto a trajetória docente se perfaz em meio "à gestão das crises, conflitos e condições adversas" (p.6). Isto quer dizer que "a docência constitui-se como um espaço para além da dimensão técnica, sendo atravessada não só por conhecimentos, mas também por relações interpessoais e vivências afetivas, valorativas e éticas" (p.11). Não se pode esquecer, portanto, que "existe uma ambiência que define as possibilidades de agir, condições objetivas, subjetivas e intersubjetivas em que se exerce a profissão, envolvendo, conseqüentemente, a qualidade da ação pedagógica, das relações interpessoais e da vida em geral" (p.12).

Dessa forma, as autoras elucidaram que "A ambiência docente precisa ser entendida como um processo decisivo para o sucesso da ação educativa, comprometendo assim, as instituições, exigindo que estas criem contextos favoráveis ao desenvolvimento profissional dos formadores e dos sujeitos em formação" (MACIEL, ISAIA e BOLZAN, Op. Cit. p. 14).

Mury (2011, p. 1-2) ao discutir sobre a profissionalização docente em suas articulações entre aderência e vocação, define-a como "uma construção histórica, envolvida e influenciada por contextos específicos e, por isso, marcada por diferentes características a partir de elementos agregados a ela de acordo com as experiências de formação dos professores e, ainda, com os espaços e tempos de sua atuação".

A autora considera ser de suma importância problematizar a atividade docente, assim como os processos de profissionalização pelos quais passa o professor, justificando tal argumento a partir do seguinte preceito:

Pensar a atividade docente e, especialmente, sua profissionalização como objeto de pesquisa, contudo, nos impele a vislumbrá-la não como um elemento em si, mas como componente de um todo mais amplo, qual seja, a ação de sujeitos ímpares numa atividade diversificada por seus contextos de ação e, ainda, pela individualidade que permeia o fazer pedagógico (MURY, Op. Cit., p. ).

Portanto, tanto a atividade como a profissionalização docente está permeada por diversas interferências e a existência desses fatores torna peculiar cada prática educativa, assim como os processos pedagógicos adotados.

O estudo de Powaczuk e Bolzan (2011, p. 1) se ateve "aos processos envolvidos na construção da docência universitária, focalizando as relações que perpassam o fazer-se docente neste nível de ensino". Ressaltam que "um estudo que contemple uma investigação acerca das trajetórias de formação e a relação com as ações docentes empreendidas seja capaz de trazer elementos que auxilie a compreender o caminho que os profissionais percorrem na produção de sua professoralidade". Isto significa que:

Este processo diz respeito aos movimentos de criação que o professor é capaz de produzir ao longo de sua trajetória docente, configurando novos modos de pensar, agir e sentir-se professor. Uma produção particular que envolve componentes pessoais e profissionais dinamizados a partir de uma contextura social da qual emergem valores, concepções e significados acerca da profissão docente, os quais abrigam tanto possibilidades, como limitações. Isso significa dizer que as vivencias pelas quais os professores 
passam ao longo de seu percurso formativo podem incidir sobre o fazer-se docente de modo distinto, tendo em vista as possibilidades de interpretação e de [re]significação que este traz consigo nos diferentes momentos de sua trajetória (POWACZUK e BOLZAN, Op. Cit., p. 1).

Existem, portanto, dimensões pessoais e profissionais que auxiliam no processo de profissionalização do professor, o qual sofre influências e reage a elas no decorrer de sua trajetória de formação e atuação. A esse respeito, dizem:

a professoralidade caracteriza-se como um movimento prospectivo de desenvolvimento da docência, sublinhando a estreita relação entre as potencialidades do sujeito e as condições contextuais no qual ela acontece, remetendo-nos a pensar que mesmo existindo uma realidade interna, esta adota cursos e formas dependentes do contexto cultural onde o individuo encontra-se submerso, ou seja, ela se dá a partir do entrecruzamento do plano individual e do plano social, gerando uma configuração única para cada indivíduo (POWACZUK e BOLZAN, Op. Cit., p. 3).

Nota-se que o contexto cultural do ambiente institucional em que o docente transita, convive, trabalha, influencia sobremaneira o desenvolvimento de sua professoralidade. $\mathrm{O}$ interesse individual mescla-se com as demandas sociais e regramentos institucionalizados, permitindo aflorar suas potencialidades ou limitando-as por força da cultura já instituída no ambiente de trabalho.

Concernente à atividade de formação Powaczuk e Bolzan, (Idem., p. 9) percebem as autoras a importância estratégica que ela assume no percurso de vida profissional do docente universitário, o que demanda tempo e espaço para concretizá-la.

A atividade de formação caracteriza-se pela sua intencionalidade a compor uma atividade de ensino profissional e, consequentemente, fundamentada. Um processo marcado pela dimensão reflexiva e pelas condições concretas nas quais esta é desenvolvida, tendo em vista que esta exige espaços/ tempos sistematicamente organizados.

Os processos formativos, portanto, refletem certos interesses pessoais, mas também estão associados às exigências colocadas para o exercício de uma atividade profissional. Assim, embora seja reconhecido que "as oportunidades afetivas, sociais, políticas, culturais e institucionais influenciam diretamente no modo de produção da docência", no âmbito universitário, o exercício do trabalho docente "tem se pautado em indicativos referentes à titulação e a produção de pesquisa, induzidos pelas exigências acadêmicas e seus órgãos reguladores". Essas argumentações são suficientemente esclarecedoras para demonstrar que

a consolidação do desenvolvimento profissional docente nas IES implicaria a participação e a tomada de decisões compartilhadas, viabilizando o fomento, a análise e a reflexão acerca das práticas formativas no seu interior. Pois o desenvolvimento profissional docente não pode ser pensado em uma perspectiva individual, ele necessita ser assumido coletivamente e institucionalmente, integrando processos voltados à melhoria das condições do trabalho docente e de ações transformadoras do ensino (POWACZUK e BOLZAN, Op. Cit., p. 14).

Isto significa que o processo de formação do docente universitário, ao mesmo tempo em que representa um empreendimento individual, requer sistemática participação das instituições educativas nas quais se realiza o trabalho do professor, posto exigir estrutura 
adequada ao desempenho da atividade laboral, tanto no que concerne ao ensino, quanto à qualificação e produtividade científica.

As análises que efetuei a partir das informações colhidas do Currículo Lattes referentes às pesquisadoras, possibilitaram organizar os resultados em quatro eixos de reflexão que versam sobre a escolarização, a atuação em grupos de pesquisa, os produtos científicos e os meios adotados para divulgação, e os objetos das pesquisas desenvolvidas.

No primeiro deles, denominado $A$ formação acadêmica das mulheres pesquisadoras no campo da educação, fez-se a análise do percurso de escolarização trilhado pelas docentes pesquisadoras, com ênfase aos níveis de graduação, pós-graduação e estágio pós-doutoral.

Em termos de titulação, as pesquisadoras, portanto, apresentam perfis acadêmicos que se assemelham quando se trata do ensino de graduação, mestrado e doutorado, porém, nem todas passaram pela especialização e o estágio pós-doutoral. Por outro lado, percebeuse que os sujeitos vinculados aos Programas de Pós-Graduação em Educação das instituições selecionadas para estudo provêm de áreas de concentração diferentes, sendo rarefeita a proporção daqueles que desde o ensino de graduação palmilharam o campo da educação.

No âmbito do ensino de graduação, os docentes freqüentaram cursos diferentes e em momentos históricos diversos, sendo que três obtiveram a conclusão em apenas um curso, enquanto um deles finalizou quatro.

Considerando-se somente o primeiro curso em que o docente se graduou, percebeuse que as opções recaíram sobre Filosofia, Pedagogia, Educação Física e Enfermagem e Obstetrícia. As universidades federais do Amazonas, Pará, Rondônia e do Rio de Janeiro, constituíram os espaços acadêmicos priorizados nessa formação.

No âmbito da especialização, apenas três professores $(75 \%)$ transitaram por esse nível de aprimoramento, porém, um deles (25\%) ficou desprovido desse processo formativo. Além disso, dois professores se submeteram a mais de um curso, com fundamentos em áreas diversas.

O preparo das docentes pesquisadoras no nível de especialização teve como foco o planejamento educacional, a gestalterapia, administração dos serviços de saúde, didática do ensino superior, ensino de dança, medicina desportiva e biociência dos esportes, saúde pública, administração de serviços de enfermagem, e administração hospitalar.

O tempo em que os docentes freqüentaram a especialização sofreu variação cronológica que se estendeu no intervalo histórico 1972-1996. Ressalte-se que as instituições em que estudaram eram predominantemente nacionais, mas um deles teve a experiência de participar de uma universidade localizada nos Estados Unidos da América.

No caso da formação para a pesquisa no nível do mestrado, dois professores iniciaram seu preparo no ano de 1976, embora tenham concluído em períodos diferentes, um no ano de 1978 e outro um ano após. Houve um docente que iniciou de 1987 e concluiu em 1989, ingressando em novo mestrado no ano de 2000 com desfecho em 2001. Outro docente adentrou em 1990 e finalizou em 1993.

Dentre esses professores agora submetidos ao preparo para a pesquisa, dois deles optaram pela área de educação (50\%), um escolheu a de filosofia $(25 \%)$ e outro a pedagogia do movimento humano e posteriormente tecnologia educacional (25\%). Destaque-se que as instituições que abrigaram os docentes eram todas nacionais, tais como: Pontifícia Universidade Católica do Rio de Janeiro, PUC-Rio; Universidade de Brasília, UNB; Universidade Gama Filho, UGF; e a Universidade do Estado do Rio de Janeiro, UERJ. Apenas uma pesquisadora obteve sua formação em instituição estrangeira, porém, depois de já ter alcançado a titulação no nível de mestrado.

Com relação ao doutorado, o tempo de ingresso e conclusão oscilou entre 1982 a 2002. Um docente ingressou em 1982 e finalizou no ano de 1984; outro iniciou em 1988 e 
terminou seis anos após; houve caso de um pesquisador que passou a freqüentar no ano de 1995 e defendeu sua tese no ano de 1999; um deles deu início em 1997 e chegou ao termo final no ano de 2002. Nota-se que entre o tempo de início e conclusão do doutorado as pesquisadoras consumiam prazos diferenciados para obtenção da titulação, os quais variavam entre 2, 4, 5 e 6 anos.

As áreas de concentração em que as autoras escolheram para investimento intelectual na produção de suas teses doutorais privilegiaram os campos da Filosofia, Ciências da Educação, Educação, Desenvolvimento Sustentável do Trópico Úmido. Portanto, 50\% das pesquisadoras tiveram o foco na educação, enquanto $50 \%$ escolheram distintos ramos do conhecimento.

Os Programas de Pós-Graduação freqüentados pelas pesquisadoras eram de origem nacional $(50 \%)$ ou estrangeira, mas, neste caso, 25\% estudaram na França e $25 \%$ na Espanha. No contexto brasileiro, as instituições escolhidas foram: Universidade Gama Filho - UGF e a Universidade Federal do Pará - UFPA. Os espaços acadêmicos internacionais ficaram representados pela Université Des Sciences Et Technologies de Lille e a Universidad Rovira i Virgili.

TABELA n 01: Trajetórias de formação das pesquisadoras

\begin{tabular}{|c|c|c|c|c|c|}
\hline $\begin{array}{c}\text { Docente } \\
\text { Pesquisadora }\end{array}$ & \multicolumn{5}{|c|}{ Nível de Escolarização } \\
\hline & Graduação & Especialização & Mestrado & Doutorado & $\begin{array}{c}\text { Estágio Pós- } \\
\text { Doutoral }\end{array}$ \\
\hline $\begin{array}{l}\text { Rosa Mendonça } \\
\text { de Brito }\end{array}$ & $\begin{array}{l}1970 \quad 1973 \\
\text { Graduação } \quad \text { em } \\
\text { Filosofia. Universidade } \\
\text { Federal do Amazonas, } \\
\text { UFAM, Brasil. }\end{array}$ & & $\begin{array}{l}\text { 1976 - 1979 Mestrado } \\
\text { em } \quad \text { Filosofia. } \\
\text { Pontifícia } \\
\text { Universidade } \\
\text { do Rio de Jálica } \\
\text { PUC-Rio, Brasil. }\end{array}$ & $\begin{array}{l}1982 \text { - } 1984 \text { Doutorado em } \\
\text { Filosofia. Universidade } \\
\text { Gama Filho, UGF, Brasil. }\end{array}$ & \\
\hline $\begin{array}{l}\text { Olgaíses Cabral } \\
\text { Maués }\end{array}$ & $\begin{array}{l}\text { 1964-1969: Graduação } \\
\text { em } \quad \text { Pedagogia. } \\
\text { Universidade Federal } \\
\text { do Pará, UFPA, Brasil. }\end{array}$ & $\begin{array}{l}\text { 1972-1972: Especialização } \\
\text { em } \quad \text { Planejamento } \\
\text { Educacional. California } \\
\text { State University San } \\
\text { Diego }\end{array}$ & $\begin{array}{l}\text { 1976 - 1978 Mestrado } \\
\text { em Educação } \\
\text { Universidade de } \\
\text { Brasília, UNB, Brasil }\end{array}$ & $\begin{array}{l}\text { 1988-1994: Doutorado em } \\
\text { Sciences de L'éducation. } \\
\text { Université Des Sciences Et } \\
\text { Technologies de Lille. } \\
\text { França. }\end{array}$ & $\begin{array}{l}\text { 2002-2002: Pós- } \\
\text { Doutorado. } \\
\text { Université Laval. } \\
\text { Canadá. } \\
\text { 2008: Pós- } \\
\text { Doutorado. } \\
\text { Universidade } \\
\text { Federal de São } \\
\text { Carlos. Brasil. }\end{array}$ \\
\hline $\begin{array}{l}\text { Tânia Suely } \\
\text { Azevedo } \\
\text { Brasileiro }\end{array}$ & $\begin{array}{l}\text { 2004-2004: Graduação } \\
\text { em Pedagogia. } \\
\text { Faculdades Integradas } \\
\text { de Ariquemes, FIAR, } \\
\text { Brasil. } \\
\text { 1994-1997: Graduação } \\
\text { em Psicologia } \\
\text { Universidade Federal } \\
\text { de Rondônia, UNIR, } \\
\text { Brasil. } \\
\text { 1994-1996: Graduação } \\
\text { em Licenciatura em } \\
\text { Psicologia. } \\
\text { Universidade Federal } \\
\text { de Rondônia, UNIR, } \\
\text { Brasil. } \\
\text { 1976-1978: Graduação } \\
\text { em Educação Física. } \\
\text { Universidade Federal } \\
\text { de Juiz de Fora, UFJF, } \\
\text { Brasil. }\end{array}$ & $\begin{array}{l}\text { 1996-1996: Especialização } \\
\text { em Gestalterapia . Instituto } \\
\text { Brasileiro de } \\
\text { Gestalterapia. } \\
\text { 1994-1994: Especialização } \\
\text { em Administração dos } \\
\text { Serviços de Saude. } \\
\text { Universidade de Ribeirão } \\
\text { Preto, UNAERP, Brasil. } \\
\text { 1985-1985: Especialização } \\
\text { em Ensino da Dança } \\
\text { Universidade Gama Filho, } \\
\text { UGF, Brasil. } \\
\text { 1985-1985: Especialização } \\
\text { em Didática do Ensino } \\
\text { Superior. Universidade } \\
\text { Gama Filho, UGF, Brasil. } \\
\text { 1980-1980: Especialização } \\
\text { em Medicina Desportiva e } \\
\text { Biociências do Esporte. } \\
\text { Universidade Federal de } \\
\text { Juiz de Fora, UFJF, Brasil. }\end{array}$ & $\begin{array}{l}\text { 1987-1989: Mestrado } \\
\text { em Pedagogia do } \\
\text { Movimento Humano. } \\
\text { Universidade Gama } \\
\text { Filho, UGF, Brasil. } \\
\text { 2000-2001: Mestrado } \\
\text { em Tecnologia } \\
\text { Educacional. } \\
\text { Universidad Rovira i } \\
\text { Virgili. Espanha. }\end{array}$ & $\begin{array}{lr}\text { 1997-2002: } & \text { Doutorado em } \\
\text { Educação. } & \text { Universidad } \\
\text { Rovira i Virgili. Espanha. }\end{array}$ & $\begin{array}{lr}\text { 2008-2009: } & \text { Pós- } \\
\text { Doutorado. } & \\
\text { Instituto } & \text { de } \\
\text { Psicologia } & \text { da } \\
\text { USP. } & \\
\text { 2009-2009: } & \text { Pós- } \\
\text { Doutorado. } & \\
\text { Universidade } & \text { de } \\
\text { La Havana - Cuba. }\end{array}$ \\
\hline $\begin{array}{l}\text { Elizabeth } \\
\text { Teixeira }\end{array}$ & $\begin{array}{l}\text { 1977-1980: Graduação } \\
\text { em Enfermagem e } \\
\text { Obstetrícia. } \\
\text { Universidade Federal } \\
\text { do Rio de Janeiro, } \\
\text { UFRJ, Brasil. }\end{array}$ & $\begin{array}{l}\text { 1984-984: Especialização } \\
\text { em Saúde Pública. Centro } \\
\text { de Ensino Unificado de } \\
\text { Brasília. } \\
\text { 1984-1984: Especialização } \\
\text { em Administração de } \\
\text { Serviço de Enfermagem. } \\
\text { Universidade de Brasília, } \\
\text { UNB, Brasil. } \\
\text { 1983-1984: Especialização } \\
\text { em Administração } \\
\text { Hospitalar. Centro de } \\
\text { Ensino Unificado de } \\
\text { Brasília. }\end{array}$ & $\begin{array}{l}\text { 1990-1993: Mestrado } \\
\text { em Educação. } \\
\text { Universidade do } \\
\text { Estado do Rio de } \\
\text { Janeiro, UERJ, Brasil. }\end{array}$ & $\begin{array}{l}\text { 1995-1999: Doutorado em } \\
\text { Desenvolvimento } \\
\text { Sustentável do Trópico } \\
\text { Úmido. } \\
\text { Federal do Pniversidade } \\
\text { Brasil. }\end{array}$ & $\begin{array}{l}\text { 2001-2002: Pós- } \\
\text { Doutorado. } \\
\text { Universidade de } \\
\text { Coimbra, } \\
\text { Portugal. }\end{array}$ \\
\hline
\end{tabular}


Depois de alcançada a formação de pesquisadora no mestrado, consolidado a qualificação de alto nível no doutorado, as docentes passaram a demandar aprimoramentos por meio da realização do Estágio Pós-Doutoral, tanto no Brasil (Universidade Federal de São Carlos, Instituto de Psicologia da USP), quanto nos países estrangeiros (Universidade de La Havana - Cuba, Université Laval - Canadá, e Universidade de Coimbra - Portugal). Assim, $75 \%$ delas vivenciaram essa experiência, e apenas uma ainda não possui tal inserção.

As experiências pós-doutorais empreendidas pelas pesquisadoras ocorreram entre os anos de 2001-2009. A docente ligada ao PPGED-UEPA foi a primeira a participar, com início no ano de 2001 e término em 2002. No caso da professora vinculada ao PPGEDUFPA, seus estudos ocorreram por duas vezes, uma no ano de 2002 e outra em 2008. Para a pesquisadora do PPGED-UNIR, também houve o cômputo de duas oportunidades, uma que se estendeu de 2008-2009 e outra realizada no ano de 2009.

Verifica-se que uma vez obtida a titulação no nível de graduação, as pesquisadoras se devotaram ao aprimoramento da formação profissional, o que implicou investimentos acadêmicos visando ingresso e conclusão nos cursos de especialização, mestrado, doutorado e no estágio de pós-doutoramento. Raras foram aquelas que deixaram de participar do lato sensu, como também do pós-doutorado.

Em termos de titulação, as pesquisadoras apresentam perfis acadêmicos que se assemelham quando se trata do ensino de graduação, mestrado e doutorado, porém, nem todas passaram pela especialização e o estágio pós-doutoral. Por outro lado, percebeu-se que os sujeitos vinculados aos Programas de Pós-Graduação em Educação das instituições selecionadas para estudo têm sua proveniência em áreas de concentração diferentes, sendo rarefeita a proporção daqueles que desde o ensino de graduação transitaram pelo campo da educação.

\section{Participação em grupos de pesquisa certificados pela instituição em que atua}

$\mathrm{O}$ segundo momento foi dedicado ao estudo relacionado à Participação em grupos de pesquisa certificados pela instituição em que atua, a fim de verificar a representatividade docente na liderança e participação nos grupos de pesquisa institucionalizados.

Verificou-se que o surgimento dos grupos de pesquisa permitiu às docentes congregar nesses espaços pesquisadores e estudantes com o propósito de desenvolver estudos e reflexões atinentes a temáticas diversas, assim como se constituíram elementos estruturais institucionais de grande valia tanto na congregação de profissionais em torno da área de educação, quanto vem permitindo a produção de conhecimento científico e a captura de investimentos financeiros capazes de viabilizar as políticas de intercâmbio acadêmicocientífico no interior das instituições universitárias e na escola básica brasileira.

Além de assegurar a execução dos projetos de pesquisa dos seus líderes, por meio dos grupos de pesquisa tem sido possível potencializar a realização de investigações por parte dos alunos de graduação escolhidos nos processos seletivos para ingresso na Iniciação Científica, bem como investir na produção de dissertações de mestrado e teses de doutorado entre os discentes da pós-graduação em educação. Por outro lado, a dinâmica desses grupos incide sobremaneira em acúmulos teóricos e pragmáticos traduzidos em artigos em periódicos, livros, e capítulos de livros que circulam em diferentes veículos de propagação do saber científico.

Notícia recente divulgada em 2010 no Jornal Beira do Rio ${ }^{2}$ revela que "Grupos fortalecem investigação científica". Inserida nesse cenário, "A UFPA é a maior universidade do Norte do Brasil em número de grupos de pesquisa e ocupa a $28^{\text {a }}$ colocação nesse ranking nacional". A respeito da importância atingida pelos grupos no contexto dessa instituição,

Os dados revelam que a UFPA possuía 228 Grupos de Pesquisa cadastrados no CNPq em 2008, o que corresponde a 60,15\% do total de 
grupos do Estado do Pará e 21,30\% do total de grupos registrados em toda a Região Norte. A Universidade conta, ainda, com 1.219 pesquisadores, o equivalente a $52,53 \%$ do total de profissionais que trabalham com pesquisa em solo paraense e $19,92 \%$, das pessoas que fazem pesquisa no norte do País, sendo que $59,1 \%$ deles são doutores.

Os grupos se apresentam como relevantes espaços de produção científica, contam com apoio institucional e potencializam relações entre pesquisadores de diversas áreas do conhecimento. Além disso, estimula-se a participação dos acadêmicos de graduação e pósgraduação, assim como dos técnico-administrativos em torno da investigação.

Além dos 228 certificados em 2008, a UFPA criou 10 novos grupos em
2009 , 49 estão em fase de criação e outros 55 precisam atualizar suas
informações para fazerem parte do cadastro. Atualmente, 1.355
pesquisadores, 1.671 estudantes de graduação e pós-graduação e 151
técnico-administrativos da UFPA estão engajados em grupos de
investigação científica na Instituição, em uma das suas 883 linhas de
pesquisa.

Embora se perceba uma tendência à ampliação dos integrantes nos grupos de pesquisa, a proporção de docentes, alunos e técnico-administrativos envolvidos ainda é extremamente baixa em termos da capacidade de absorção.

Analisando-se os indicadores extraídos do Anuário Estatístico da UFPA ${ }^{3}$ referente ao ano de 2010, encontram-se sistematizadas as seguintes informações: 32.169 alunos matriculados no ensino de graduação e 7.101 na pós-graduação, totalizando 39.230 discentes; destes tão-somente $1.671(4,25 \%)$ participam nos grupos de pesquisa, sem contabilizar o total de 8.317 alunos vinculados ao ensino básico, médio, profissional e cursos livres; entre os 2.522 docentes vinculados à instituição, somente 1.355 são cadastrados como pesquisadores, ou seja, 53,72\% dos professores; existem 2.309 técnicoadministrativos, mas apenas 151 optam por participar dos grupos, atingindo a média de $6,53 \%$. Contudo, indiscutível o relevante papel ocupado por esses espaços no interior dessa instituição universitária, posto que

Os grupos de pesquisa representam a expansão da investigação científica e o amadurecimento da rotina acadêmica de uma universidade. Nossa prioridade, agora, é apoiar esses grupos para que eles se consolidem, conquistem cada vez mais inserção e representatividade em suas áreas de atuação e sejam autônomos na captação de recursos com as agências e fomento à pesquisa, revela Emmanuel Tourinho, pró-reitor de Pesquisa e Pós-Graduação da UFPA.

Segundo enunciam os discursos institucionais, a criação e consolidação desses grupos impactam no fortalecimento da universidade, não apenas no concernente à vida acadêmica, mas no incremento das pesquisas, na produção do conhecimento, na captação de recursos, na política de fomento à iniciação científica e na formação de mestres e doutores das distintas áreas em que se estabelecem:

Para o pró-reitor, a diversificação de Grupos de Pesquisa tem estreita relação com o fortalecimento da pós-graduação na Universidade e com a ampliação do número de doutores que atuam na Instituição. "Quanto maior o número de doutores e de pós-doutores, quanto mais servidores e alunos temos envolvidos com a pós-graduação, maior o número de pessoas que estão se dedicando a investigação científica na Universidade. Os grupos de 
pesquisa passam a se multiplicar e a diversificar, como elos que unem estes pesquisadores".

Nota-se que os grupos se converteram em espaços imprescindíveis na vida acadêmica da instituição universitária, tanto por sua dimensão pedagógica em termos do preparo científico dos jovens pesquisadores, mestres e doutores, quanto aos vínculos institucionais e interinstitucionais que potencializam a fim de estabelecer troca de experiências e produzir conhecimento sob a forma de parcerias.

Assim, o exame dos indicadores referentes aos grupos de pesquisa demonstrou o quanto esses espaços se transformaram em estratégicos locais institucionais por meio dos quais os pesquisadores têm alcançado projeção acadêmico-científica, bem como enquanto profissional atuante na área da educação.

Providas com a qualificação acadêmica nos níveis do mestrado e doutorado, as docentes partiram em busca da criação e inserção em grupos de estudos, seja na qualidade de pesquisador, ou na condição de quem exerce a liderança.

Entre os anos de 1996-2004, as professoras se mobilizaram a fim de assegurar sua participação em grupos de pesquisa, os quais se ramificaram nas seguintes temáticas: educação e cultura, história da educação na Amazônia, educação superior, universitas, psicologia escolar e educacional, atenção primária e saúde na Amazônia.

Mencionados grupos congregam docentes e estudantes de graduação e pósgraduação, ramificando-se em diferentes linhas de pesquisa que alimentam a produção científica dos seus integrantes.

Tratando-se do exercício da liderança dos grupos de pesquisa, percebeu-se que entre as quatro pesquisadoras, $75 \%$ cumprem esse papel concomitante com o vínculo estabelecido com outros grupos dos quais somente participa enquanto pesquisador, porém, uma delas $(25 \%)$ restringe sua atuação na qualidade de membro.

Os temas que entrecortam as nomenclaturas dos grupos têm o foco em questões relacionadas a: educação, política e sociedade; política educacional, formação e trabalho docentes; práxis; e políticas educacionais em saúde e cuidado na Amazônia.

Após a obtenção da titulação dessas mulheres docentes no nível de doutorado, tornou-se possível o exercício da liderança em grupos de pesquisa a partir da formação destes no intervalo de 2002-2009. Dessa forma, no total dos quatro grupos registrados sob suas lideranças, $50 \%$ deles são coordenados por uma docente, restando $50 \%$ a ser partilhado equitativamente para cada um dos demais pesquisadores.

O surgimento dos grupos de pesquisa permitiu às docentes congregar nesses espaços pesquisadores e estudantes com o propósito de desenvolver estudos e reflexões atinentes a temáticas diversas, assim como se constituíram elementos estruturais institucionais de grande valia tanto na congregação de profissionais em torno da área de educação, quanto vem permitindo a produção de conhecimento científico e a captura de investimentos financeiros capazes de viabilizar as políticas de intercâmbio acadêmico-científico no interior das instituições universitárias e na escola básica brasileira.

Além de assegurar a execução dos projetos de pesquisa dos seus líderes, por meio dos grupos de pesquisa tem sido possível potencializar a realização de investigações por parte dos alunos de graduação selecionados nos processos seletivos para ingresso na Iniciação Científica, bem como investir na produção de dissertações de mestrado e teses de doutorado entre os discentes da pós-graduação em educação. Por outro lado, a dinâmica desses grupos incide sobremaneira em acúmulos teóricos e pragmáticos traduzidos em artigos em periódicos, livros, e capítulos de livros que circulam em diferentes veículos de propagação do saber científico. 
TABELA no 02: Vínculo das pesquisadoras com Grupos de Pesquisa

\begin{tabular}{|c|c|c|}
\hline \multirow{2}{*}{$\begin{array}{c}\text { Docente } \\
\text { Pesquisadora }\end{array}$} & \multicolumn{2}{|c|}{ Grupos de pesquisa a que se vincula } \\
\hline & Líder & Pesquisador \\
\hline $\begin{array}{l}\text { Rosa Mendonça } \\
\text { de Brito }\end{array}$ & & $\begin{array}{l}\text { Educação, cultura e desafios amazônicos - UFAM. } \\
\text { Ano de formação } 2000 \text {. } \\
\text { Grupo de Estudos e Pesquisas em História da } \\
\text { Educação na Região Amazônica - GEPHEAM - } \\
\text { UFAM. Ano de formação 2004. }\end{array}$ \\
\hline $\begin{array}{l}\text { Olgaíses Cabral } \\
\text { Maués }\end{array}$ & $\begin{array}{l}\text { Educação, Política e Sociedade - UFPA. } \\
\text { Ano de formação } 2002 \text {. } \\
\text { Grupo de Estudo e Pesquisa de Política } \\
\text { Educacional, Formação e Trabalho } \\
\text { Docente - UFPA. Ano de formação } 2009 .\end{array}$ & $\begin{array}{l}\text { GEPES/UFPA - Grupo de Estudos e Pesquisas sobre } \\
\text { Educação Superior - UFPA. Ano de formação } 1996 . \\
\text { UNIVERSITAS/RIES - PUCRS. Ano de formação } \\
1997 .\end{array}$ \\
\hline $\begin{array}{l}\text { Tânia Suely } \\
\text { Azevedo } \\
\text { Brasileiro }\end{array}$ & PRAXIS - UNIR. Ano de formação 2004. & $\begin{array}{l}\text { Psicologia Escolar e Educacional: processos de } \\
\text { escolarização e atividade profissional em uma } \\
\text { perspectiva crítica - USP. Ano de formação } 2004 \text {. }\end{array}$ \\
\hline $\begin{array}{l}\text { Elizabeth } \\
\text { Teixeira }\end{array}$ & $\begin{array}{l}\text { Práticas Educativas em Saúde e Cuidado } \\
\text { na Amazônia - PESCA - UEPA. Ano de } \\
\text { formação } 2007 .\end{array}$ & $\begin{array}{l}\text { Grupo Interdisciplinar de Pesquisa em Atenção } \\
\text { Primária e Saúde na Amazônia - UFPA. Ano de } \\
\text { formação } 2010 \text {. } \\
\text { Saúde, trabalho e Meio Ambiente - UFPA. Ano de } \\
\text { formação } 1997 \text {. }\end{array}$ \\
\hline
\end{tabular}

Uma leitura dos indicadores contidos no gráfico abaixo revela que entre os 116 integrantes dos grupos liderados por três pesquisadoras, atualmente estão abrigados 55 pesquisadores $(47,41 \%), 38$ estudantes de graduação (32,75\%), 17 mestrandos $(14,65 \%), 5$ doutorandos $(4,31 \%)$ e 1 técnico $(0,86 \%)$.

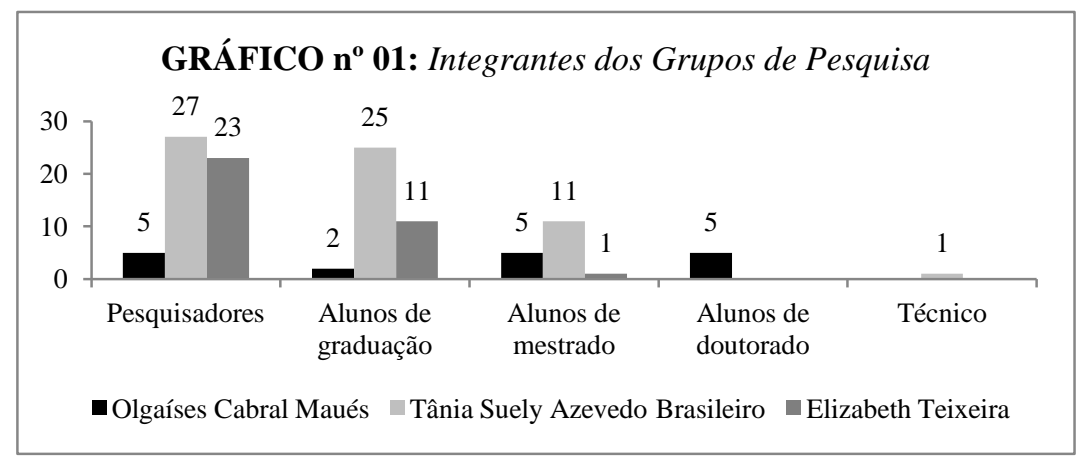

Os grupos liderados por Tânia Suely Azevedo Brasileiro e Elizabeth Teixeira são aqueles com maior expressão em termos de pesquisadores e alunos de graduação. A primeira líder, contudo, igualmente se destaca quanto à quantidade de pós-graduandos no nível de mestrado e registra um técnico como participante. Aquele cuja liderança é exercida por Olgaíses Cabral Maués, por sua vez, é o único a abrigar doutorandos, mas assume a segunda posição no caso dos estudantes de mestrado.

Cabe destacar a baixa proporção de alunos oriundos dos programas de pósgraduação em educação vinculados aos grupos de pesquisa. Tal situação parece se justificar em razão do fato de que a oferta de doutorado ainda é muito recente nas instituições em que atuam profissionalmente as pesquisadoras, como também, a inexistência desse nível de qualificação em parte dos programas, o que interfere negativamente na disponibilidade das vagas nos processos seletivos.

\section{O suporte de circulação das produções científicas das pesquisadoras em educação}

No terceiro momento deste estudo, as análises foram direcionadas para $\boldsymbol{O}$ suporte de circulação das produções científicas das pesquisadoras em educação, neste caso, deu-se prioridade aos produtos transformados em Artigos completos publicados em periódicos, Livros publicados/organizados ou edições, Capítulos de livros publicados e Trabalhos completos publicados em anais de congressos.

Costa Júnior (2011) discutiu "a precarização do trabalho docente na pós-graduação no contexto da política de avaliação realizada pela Coordenação de Aperfeiçoamento de Pessoal de Nível Superior (CAPES)", com ênfase sobre a "área de educação, e os critérios 
de avaliação da política implementada pela CAPES". O autor afirma que o "produtivismo acadêmico" se converteu em "ideologia" que fundamenta as ações desenvolvidas no âmbito da "burocracia da CAPES e do CNPq". Desse modo, constatou que "O aumento da pressão exterior pela produção acaba por fazer com que os pesquisadores aumentem a pressão sobre si mesmos". É o que narra a esse respeito:

as relações de trabalho sofrem um processo de empobrecimento e de esvaziamento de sua potencialidade humanizadora. Isso porque a competitividade instalada nas relações de trabalho dada à busca por produção e visibilidade, induz a um individualismo, ou a uma falsa solidariedade, ainda quando os professores falem em nome do Programa (p. 5).

Segundo esse ponto de vista, a atividade docente estaria se tornando empobrecida e vazia quanto ao aspecto humano, decorrência do clima de competitividade que permeia o ambiente dos Programas de Pós-Graduação em Educação, onde cada professor combate no intuito de alcançar o máximo de produtividade científica, de modo a manter ou elevar o conceito atribuído pela CAPES aos Programas por ocasião de cada ciclo avaliativo.

Nesse ritmo em que a produtividade e o individualismo se convertem em regra fundamental, estaria ocorrendo uma compressão das atividades acadêmicas e "aceleração do tempo", o que repercute negativamente no trabalho docente na Pós-Graduação. Diante desse cenário, Costa Júnior (Op. Cit., p. 6) defende a assertiva de que:

O que se percebe é o cultivo de uma lógica que diferencia, promove ou pune quem é produtivo de quem não é. Por isso, nessa ordem de produção, boa parte dos trabalhos desliza para o âmbito do mero produtivismo, onde não há espaço/tempo para o pensamento e a criação, ao ócio produtivo e criativo.

Sob essa argumentação, a lógica produtivista parece se converter na razão de existir dos Programas, gerando mecanismos de controle que operam com base na premiação ou punibilidade, transformando os processos de criação científica em produtivismo, provocando a supressão do espaço e do tempo destinado à atividade docente de pesquisa, arruinando a reflexão e o uso produtivo e criativo do tempo.

No entanto, há o reconhecimento por parte do autor de que resistências são manifestadas pelos docentes a fim de confrontar as determinações oficiais emanadas dos órgãos reguladores. E é justamente nesse contexto que ocorre a subjetivação do pesquisador. Assim, as contradições entre discordar e acatar as diretrizes quantitativistas concretizam-se no cotidiano das instituições e no trabalho docente. Por isso, contradição, conflito e ajuste fazem parte desse processo de objetivação e negação de si mesmo (COSTA JÚNIOR, Idem., p. 6).

Ainda que as práticas de resistência, confronto, inconfidências aflorem entre os docentes vinculados aos Programas, a análise de Costa Júnior (Op. Cit., p. 7) demonstra o quanto a lógica produtivista sobrepuja as possíveis reações conspiratórias, quando diz:

Porém, a pressão pela produtividade alinhada às várias tarefas/funções/papéis que o professor desempenha na pós-graduação, desemboca, irreversivelmente, na desqualificação do seu produto. É impossível fazer ciência com um tempo marcado ou sem tempo adequado e necessário para a maturação da reflexão. 
Assim, o acúmulo de atividades nas quais estão envolvidos os docentes, bem como a inadequação do tempo disponível para o desenvolvimento das pesquisas, fortalece o paradigma da produtividade, o que resulta na valorização da quantidade de trabalhos publicados, ainda que parte considerável deles tenha a qualidade precária como marca emblemática de seu produto.

Por outro lado, Costa Júnior (Idem., p. 7) destaca os efeitos nefastos decorrentes da interferência da agência reguladora CAPES sobre o trabalho docente na Pós-Graduação, principalmente quanto ao condicionamento que impõe aos pesquisadores na disputa por acesso ao financiamento público dos estudos pretendidos.

\begin{abstract}
A função da CAPES de regular e controlar a produção científica por meio de editais, convênios e fundos de natureza variada, apresenta-se como condição de possibilidade do trânsito dos pesquisadores entre a universidade, o setor produtivo e a valorização do capital; movimento este que implica na imposição do tempo da economia sobre o tempo da criação e da produção do conhecimento.

Entretanto, ciência não se faz com pressa e os tempos precarizados prejudicam o espírito científico da dúvida e do debate, argumentos e teses a partir de posições contrárias. Essa relação entre a universidade e o setor produtivo precariza de forma acentuada, aquilo que é fundamental na pósgraduação: ensino, pesquisa e extensão (...)
\end{abstract}

Diante dessa situação, os docentes restariam fadados a sucumbir ante as ordens institucionais que sufocam a criatividade e precarizam a produção do conhecimento de forma autônoma, corroendo, inclusive, o chamado "espírito científico", afetando, sobretudo, o exercício da curiosidade para investigar determinadas temáticas que não aquelas de interesse do capital. Diante desse imobilizador diagnóstico, o autor enuncia: "O trabalho docente na pós-graduação se manifesta como uma engrenagem que aprisiona o professor e seu tempo, sem que ele se dê, no momento, conta do processo que o submete".

Tal idéia é reforçada ainda mais quando o autor relaciona o trabalho do pesquisador com a frustração e o fracasso, evidenciando que:

A frustração está intimamente relacionada ao sentimento de fracasso. E o
fracasso é um grande tabu na modernidade, pois se na literatura popular
temos as mais variadas receitas ensinando como podemos vencer, existe
um silêncio quando o tema é a frustração e o fracasso. O que se observa, é
a manipulação da subjetividade ao mostrar como o professor é induzido a
ser um trabalhador solitário, útil, econômico, politicamente mudo e, o que
é pior, um frustrado marcado pelo sentimento de fracasso (COSTA
JÚNIOR, Op. Cit., p. 12).

Portanto, impelido pela necessidade de não fracassar, o pesquisador tem sua atividade laboral inclinada em direção ao sucesso, mas para atingi-lo, precisa submeter o processo de construção do conhecimento científico ao ritmo empresarial ditado pelo sistema capitalista. Assim, a expansão da capacidade produtiva docente se efetiva com a precarização da saúde física e psicológica, posto que para Costa Júnior (Idem., p. 13) "A procura intensa e delirante pelo aumento da produção acaba desenvolvendo uma visível competição entre os professores da pós-graduação, conduzindo-os ao estresse, cansaço e à frustração".

Diante da lógica produtivista que orienta a política de avaliação institucional aplicada pela CAPES, Costa Júnior (Op. Cit., p. 14) percebe que o ambiente acadêmico e as atividades curriculares nele desenvolvidas parecem induzir a vivências investigativas e 
processos formativos em que "As ações pedagógicas na pós-graduação passam a ser delimitadas pela obrigação de resultados, decorrentes da cultura comercial inscrita sob a égide do capital e do cuidado do Estado Avaliador". Perante essas evidências, o autor conclui:

A pós-graduação perde a sua relativa autonomia em vista de uma crescente heteronomia em relação à produção de conhecimento, agora gerida pelo setor produtivo que financia as pesquisas sob a condição de que sua agenda seja cumprida. As transformações pelas quais passa o trabalho docente na pós-graduação são, em grande medida, impostas por essa forma da política de regulação educacional que imputa à avaliação um poder constrangedor e coercitivo sem precedentes (p. 16).

Nota-se que a geração de conhecimento científico tem sido condicionada, em certa medida, pelas demandas do setor produtivo, o que impacta, também, na maneira de como se exerce o trabalho docente junto aos Programas de Pós-Graduação. Contudo, a política reguladora expressa na presença do Estado Avaliador, embora se configure como modelo constrangedor e coercitivo que precariza a reflexão e criatividade dos professores, não é irreversível e tampouco imobiliza o pesquisador na sua capacidade de transgressão e resistência.

Campos $(2011$, p. 2) refletiu sobre "os sentidos e os significados de docência no ensino superior expressos nas representações de mestrandos e doutorandos de instituições federais de ensino superior das diversas áreas do conhecimento e das regiões geográficas do Brasil”. São enfáticas as descobertas a que chegou, especialmente quando identificou:

a existência de um hiato entre o concebido e o vivido pelos pósgraduandos em relação à docência, tanto os que têm experiência como docentes no ensino superior como aqueles que ainda não são professores. Os mestrandos e doutorandos admitiram que não "dominam" conhecimentos pedagógicos necessários à prática docente, apesar de considerá-los importantes à docência. Seus depoimentos revelaram uma "naturalização" da docência, ou seja, a docência é "aprendida" a partir da experiência discente, inspirada em antigos professores.

Depreende-se dessas constatações que no âmbito da Pós-Graduação a dimensão pedagógica e o preparo para o exercício do magistério na educação superior raramente são incorporados nas atividades curriculares exigidas dos discentes. Tal situação revela que os Programas têm se preocupado muito mais com a dimensão do pesquisador e da produção do conhecimento científico, negligenciando a formação inicial e continuada do professor de ensino superior.

Outro aspecto que sobressai na citada pesquisa se refere ao processo de constituição do trabalho docente voltado ao ensino superior, pois a dimensão pedagógica é ressaltada como imprescindível ao exercício profissional. A esse respeito, pronuncia-se:

a docência no ensino superior amalgama-se em uma teia de significados que condicionam a sua concepção e, conseqüentemente, não é possível refletir sobre a docência vivida e concebida sem considerar a formação específica - pedagógica - enquanto dimensão imprescindível à profissão docente (CAMPOS, Op. Cit., p. 3).

Embora estejam em circulação diversos significados sobre o exercício da docência, as reflexões envolvendo as vivências no ofício do magistério superior devem considerar os aspectos concernentes à dimensão pedagógica que orienta as condutas desses profissionais. 
Claro está que a docência se destaca como um dos atributos básicos na produção da identidade do professor universitário. Assim, a autora conceitua da seguinte forma:

Considera-se que a docência, independente do nível de ensino em que ela aconteça, é uma ação humana. Reconhecer a dimensão humana da docência é admitir, assumir que ela se constitui histórica e socialmente e, por conseguinte, é parte integrante da identidade profissional do professor (CAMPOS, Idem., p. 3).

Enquanto ação humana, a atividade docente se transforma no decurso da história do exercício da profissão, carregando consigo as marcas dos acontecimentos históricos gerais, assim como os reflexos das regulações e mudanças engendradas na cultura das instituições em que são desenvolvidos os trabalhos acadêmico-científicos e administrativos.

Diante das fragilidades diagnosticadas no preparo do docente para atuar na educação superior, Campos (Op. Cit., p. 8) considera que o exercício dessa profissão exige preparo profissional, portanto, não deve se constituir em meio ao improviso e às eventuais lições colhidas da prática de outrem.

Considera-se que docência no ensino superior requer formação profissional para seu exercício, ou seja, conhecimentos específicos para exercê-la adequadamente ou, no mínimo, a aquisição de conhecimentos e habilidades vinculadas à atividade docente para melhorar sua qualidade, pois compete ao professor duas responsabilidades básicas: formar profissionais para diversificadas áreas de atuação, inclusive formar futuros professores para a Educação Básica e gerar conhecimentos em suas área de conhecimento.

A satisfação dessas necessidades tem como alvo um profissional competente não apenas no aspecto referente à formação e produção do conhecimento, mas, principalmente, a qualidade do trabalho realizado, o que demanda um preparo em torno de habilidades e conhecimentos teóricos adequados ao ofício a ser desempenhado na educação superior.

Nessa perspectiva, a autora expressa a seguinte percepção sobre a função desempenhada pelo professor:

O professor, portanto, necessita fundamentar sua prática nos saberes da docência - saberes científicos, pedagógicos e experienciais -, os quais, em diálogo com os desafios do cotidiano, sustentam e possibilitam o desenvolvimento da identidade de um profissional reflexivo, crítico e pesquisador, articulado a contextos mais amplos, considerando o ensino como uma prática social (CAMPOS, Op. Cit., p. 9).

Um docente pesquisador cujo fazer seja crítico e reflexivo, requer uma formação envolta nos saberes científicos, mas também naqueles que ressaltam da experiência, bem como os oriundos da formação pedagógica, posto que, sendo ação humana, o exercício da docência se transforma em prática social cultural e institucionalmente construída com a participação efetiva do intelectual professor.

O preparo do docente com vista ao trabalho na educação superior, precisa se respaldar em discussões epistemológicas, segundo destaca a autora:

Nessa perspectiva, é imperativo pensar em políticas de formação para a docência no ensino superior que contemplem a especificidade epistemológica deste nível de ensino. Acredita-se que uma "preparação" para docência no ensino superior é insuficiente, assim como é insuficiente 
a formação profissional do professor restrita ao conhecimento específico de sua área. É preciso mais!Ser bacharel, licenciado, especialista, mestre, doutor e pós-doutor não garantem a assunção de uma profissão que tem um campo epistemológico específico que deveria orientar e configurar a ação docente (CAMPOS, Idem., p. 10).

Vê-se, assim, que as políticas de formação voltadas à docência não se restringe ao preparo intelectual nas áreas específicas, como também, não têm seu ápice na pósgraduação com a qualificação de mestres e doutores, pois estes nem sempre, desenvolvem habilidades e conhecimentos convergentes com a atividade docente, mas conexos aos atributos do pesquisador. Portanto, nem todos os profissionais que assumem essas funções no nível superior estão em condições pedagógicas de exercê-la com qualidade.

Com base na trajetória de produção científica das pesquisadoras da área de educação, tornou-se possível constatar a existência de perfis bibliométricos diferenciados entre as autoras dos trabalhos publicados, segundo evidencia a leitura dos indicadores contidos no gráfico abaixo.

No caso de Rosa Mendonça de Brito, vê-se a importância assentada nos livros e artigos completos em periódicos, mas contribui também com os trabalhos em congressos, ficando os capítulos de livros sem qualquer registro.

Olgaíses Cabral Maués tem priorizado trabalhos completos em anais de congressos, seguidos dos capítulos de livro e os artigos em periódicos na terceira opção, enquanto os livros recebem a menor participação quantitativa.

A pesquisadora Tânia Suely Azevedo Brasileiro, por sua vez, apareceu com maior incidência nos trabalhos completos em congressos, seguidos dos capítulos de livros, dos livros e a segunda menor fração atribuída aos artigos completos em periódicos.

Para Elizabeth Teixeira, porém, a ênfase recaiu nos artigos completos em periódicos, acompanhados dos capítulos de livros, livros e dos trabalhos completos em anais de congressos.

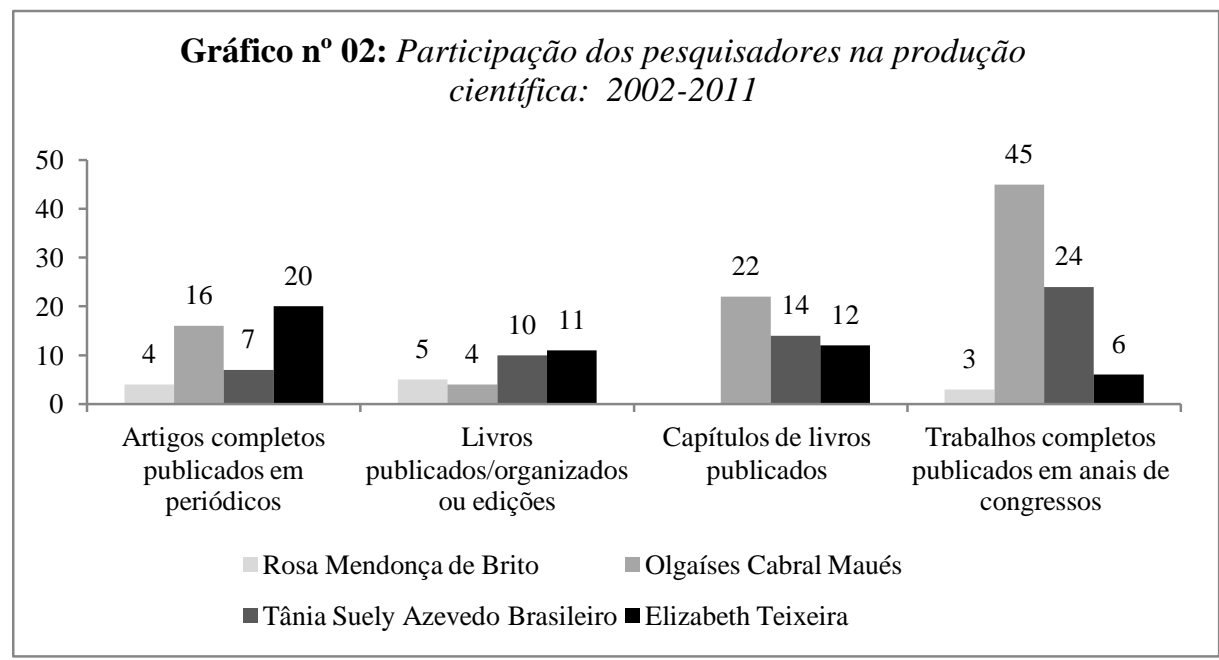

Computando-se a distribuição da produção científica segundo a participação de cada docente, foram obtidos importantes indicadores quantitativos. Do total dos 203 trabalhos divulgados no transcorrer de uma década, Olgaíses Cabral Maués aparece na primeira posição com 87 (42,85\%) produtos. Em seguida surge Tânia Suely Azevedo Brasileiro somando 55 (27,09\%). Na terceira colocação ficou a autoria de Elizabeth Teixeira acumulando 49 textos $(24,13 \%)$. A menor incidência de trabalhos foi proveniente da docente Rosa Mendonça de Brito, cujos registros apontam uma participação de 12 estudos $(5,91 \%)$. 
Do ponto de vista porcentual, os livros publicados/organizados ou edições ocupam a menor parcela da produção científica, seguido pelos trabalhos publicados sob a forma de artigos completos em periódicos. Os capítulos de livros desfrutaram da segunda classificação, enquanto os trabalhos completos divulgados nos anais de congressos atingiram a supremacia.

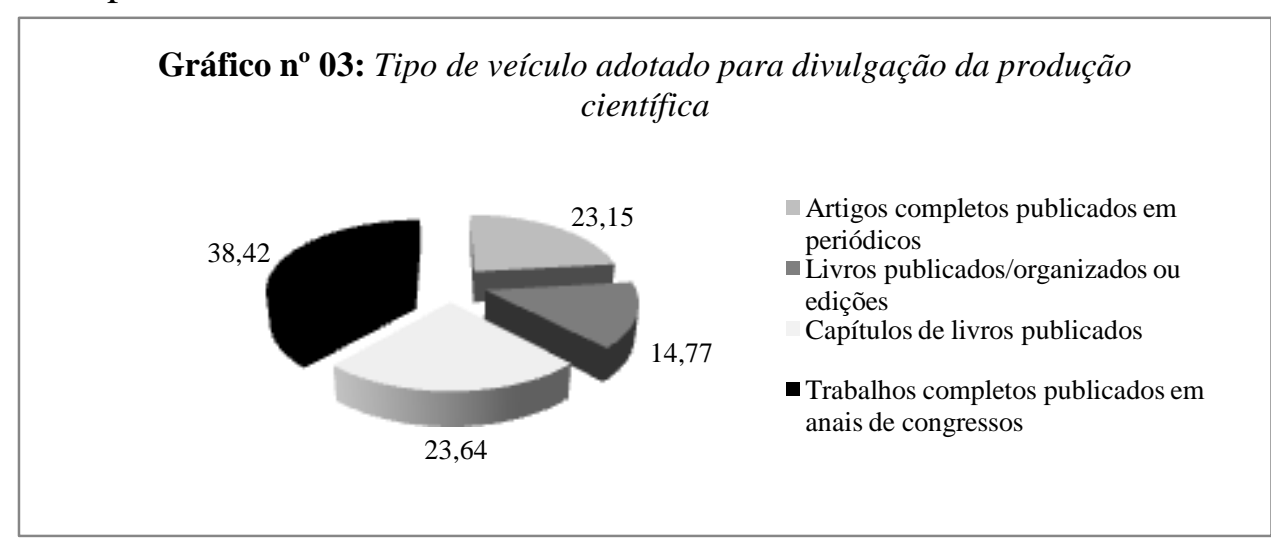

Quanto ao veículo eleito para publicação dos resultados dos estudos realizados pelas pesquisadoras, notou-se que a produção científica não alcança proporções simétricas entre elas, embora eventualmente ocorra a igualdade quantitativa em certo lapso temporal.

À medida que se diversifica o tipo de veículo adotado pela pesquisadora, diferenciase a maior e menor representatividade exercida pelas docentes dos Programas de PósGraduação em Educação. Esse fato revela a existência de oscilações na manutenção da produtividade científica. Contudo, é nos trabalhos completos publicados em anais de congressos e nos periódicos que se identifica a mais expressiva proporção dos resultados das investigações.

O crescimento verificado no âmbito da produção científica das pesquisadoras em educação demonstra o importante papel assumido pelos grupos de pesquisa, uma vez que, embora essa célula institucional se constitua espaço de poder de disputas no campo teórico, faz germinar conflitos político-ideológicos a partir de seu interior. Todavia, por meio da participação nesses grupos, tem sido possível fortalecer ações estratégicas dirigidas para o âmbito da docência e da práxis científica, sob o amparo financeiro das agências de fomento.

Decorrida uma década de produção científica, as pesquisadoras acumularam um total de 47 artigos completos aceitos para publicado em periódicos. Parte dessa quantidade adveio da contribuição da docente Elizabeth Teixeira que registrou 20 produtos $(42,55 \%)$; em segundo lugar ficou Olgaíses Cabral Maués com 16 trabalhos (34,04\%); seguida por Tânia Suely Azevedo Brasileiro que apresentou 7 textos (14,89\%); e Rosa Mendonça de Brito somando 4 artigos $(8,51 \%)$.

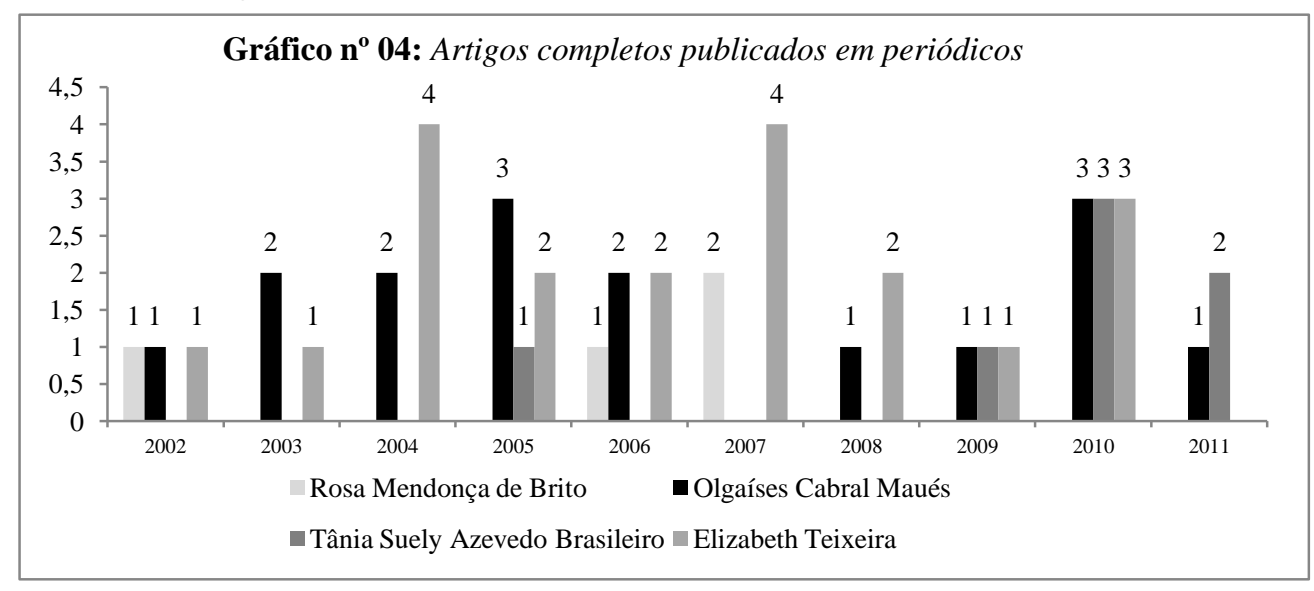


No início da série (2002-2003), verificou-se a existência de baixa circulação dos trabalhos dessas autoras nesse tipo de veículo. Porém, no intervalo compreendido entre 2004-2007, a média sofreu ampliação com valores que oscilavam entre 5 a 8 trabalhos, havendo participação diferenciada das pesquisadoras na somatória desses resultados, inclusive algumas delas não pontuaram nenhuma ocorrência em certos períodos.

Os anos de 2008, 2009 e 2011 representaram um período de declínio no volume de artigos publicados em periódicos, momento esse em que também houve redução no número das docentes escritoras. Contudo, no ano de 2010 coincidiu com a melhor fase, visto que a intensidade da produção alcançou a maior proporção no transcurso de toda a série analisada.

Quando se passa ao exame da produção que circulou por meio dos livros, nota-se que esse tipo de suporte contribuiu com a divulgação de 30 trabalhos, os quais se distribuíam de forma assimétrica, com a maior concentração obtida por Elizabeth Teixeira com 11 produtos (36,66\%) e Tânia Suely Azevedo Brasileiro registrando 10 (33,33\%). A pesquisadora Rosa Mendonça de Brito chegou a 5 livros $(16,66 \%)$ e Olgaíses Cabral Maués contribuiu com $4(13,33 \%)$.

Os indicadores organizados no gráfico abaixo permitem entender que os anos de 2002, 2003, 2004, 2005, 2007 e 2011, representaram a época com menor participação das docentes na publicação de livros. Por outro lado, os anos de 2006 e 2008 são aqueles onde se obteve a maior concentração desses produtos científicos. Todavia, a média comprimiu seu valor no ano de 2009, e com tendência à diminuição a partir do ano de 2010.

Essas informações quando comparadas àquelas relativas aos periódicos, demonstram que há maior interesse e facilidade das docentes em divulgar seus produtos nas revistas do que sob a forma de livros. Porém, tanto um quanto outro tipo escolhido, sofreu variações na quantidade dos trabalhos produzidos, o que implica em oscilações para cima ou com tendência de queda no número dos estudos que ganham visibilidade mediante sua publicação.

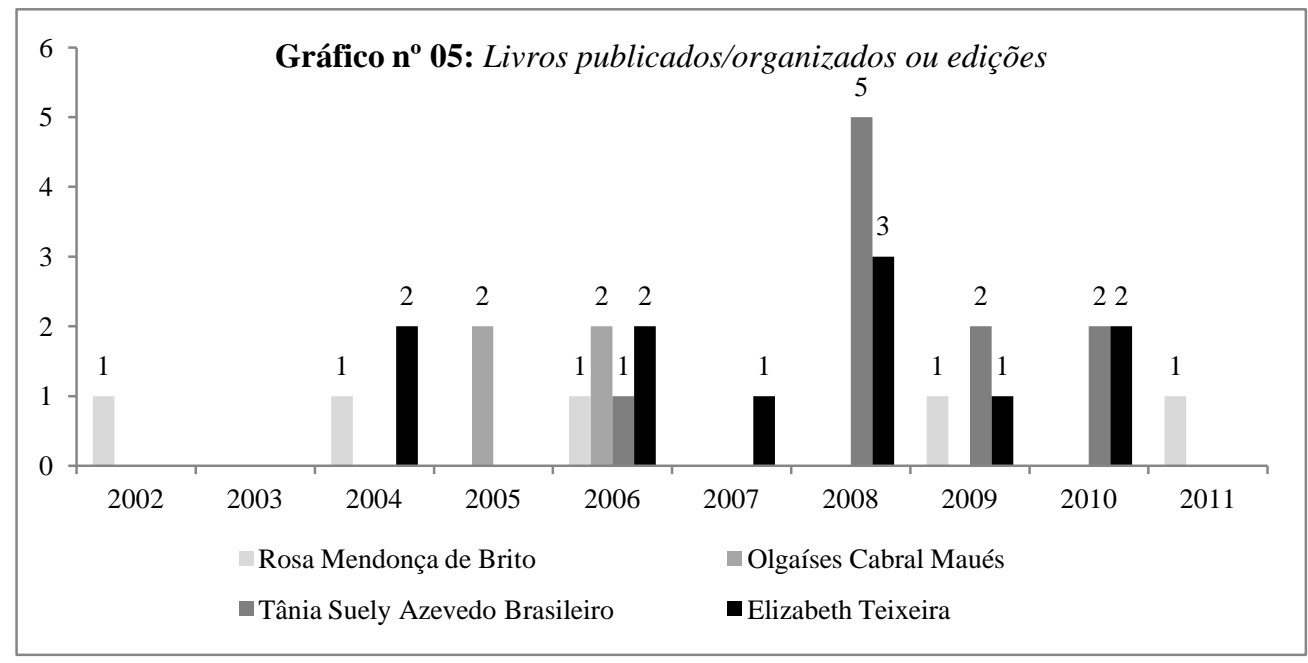

No caso dos capítulos de livros, os indicadores analisados igualmente revelaram tendência de elevação e queda na quantidade dos produtos, bem como na proporção atingida individualmente pelas pesquisadoras.

No ano de 2002 e 2011, foi computado apenas um capítulo. Contudo, a fase envolvendo o intervalo de 2003-2006, apresentou progressiva ampliação na quantidade dos trabalhos publicados. Tendo experimentado novo declínio no ano de 2007, porém retomando o ritmo de crescimento nos anos de 2008, 2009 e 2010.

Considerando-se a participação de cada pesquisadora no acúmulo dos trabalhos publicados como capítulos de livros, observa-se que uma docente não teve nenhum produto registrado, enquanto Olgaíses Cabral Maués somou 22 (45,83\%); Tânia Suely Azevedo 
Brasileiro participou com $14(29,16 \%)$ e Elizabeth Teixeira contribuiu com 12 trabalhos $(25 \%)$.

Interessante notar a ocorrência de certo revezamento na publicação dos capítulos entre as pesquisadoras, uma vez que nem sempre elas aparecem juntas no mesmo período histórico em que são informados os valores estatísticos. A exceção fica com os anos 2007 e 2010, onde houve registro da presença de três delas.

Diferentemente do ocorrido com os livros, os capítulos de livros se converteram em um tipo de veículo bastante valorizado pelos pesquisadores, chegando a atingir uma quantidade de 48 produtos, superando, portanto, a média registrada para o caso dos periódicos e dos livros anualmente publicados.

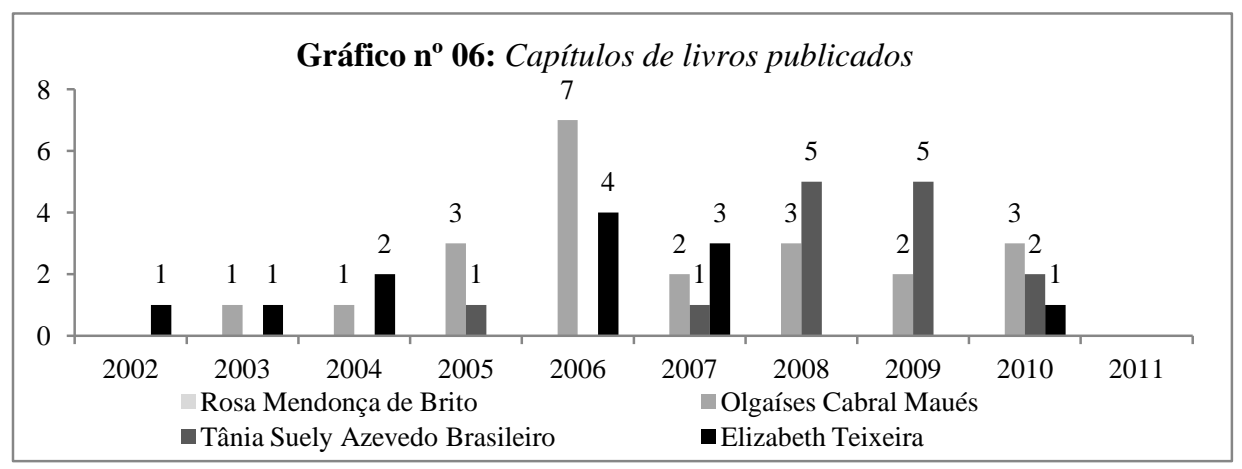

Outro tipo de veículo escolhido pelas docentes pesquisadoras, a fim de dar vazão aos produtos de suas atividades científicas, assenta sua representação nos trabalhos completos periodicamente publicados em anais de congressos.

No decorrer de dez anos, houve intensificação da produção, mas ela se distribuiu de forma desigual entre as docentes. Foram totalizados 70 trabalhos completos, dos quais 45 $(57,69 \%)$ resultaram dos esforços de Olgaíses Cabral Maués; sendo a segunda colocação ocupada por Tânia Suely Azevedo Brasileiro com 24 produtos (30,76\%); enquanto Elizabeth Teixeira somou $7(8,97 \%)$ e a docente Rosa Mendonça de Brito teve a participação aferida com 3 textos $(3,84 \%)$.

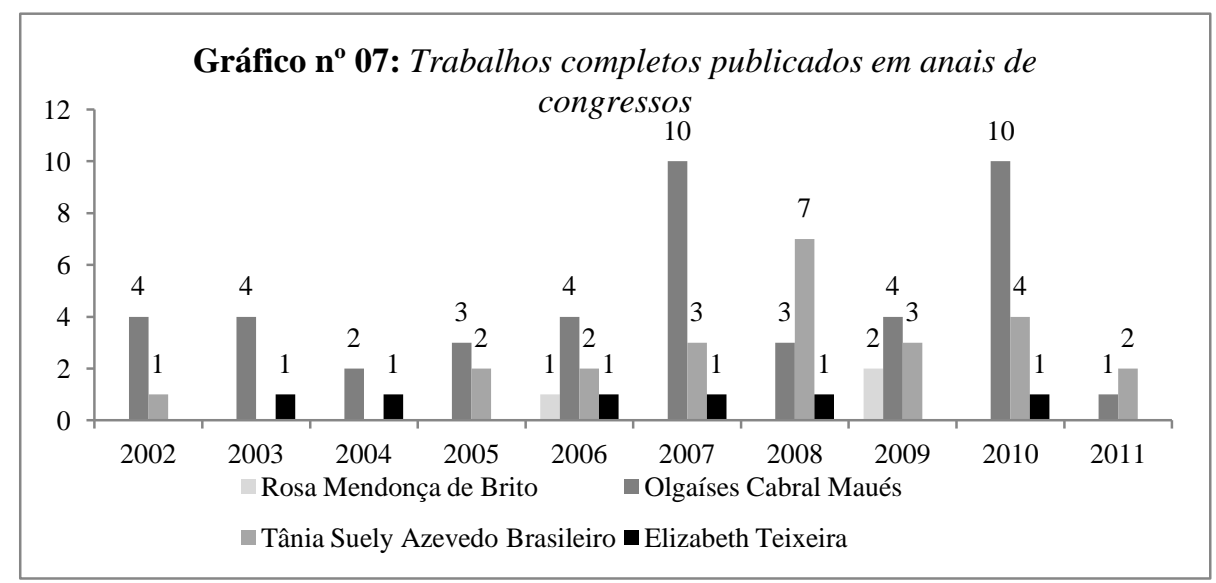

Com base nos indicadores estatísticos, fica evidente que nem todas as pesquisadoras publicaram trabalhos completos em congressos. Cito como exemplo o que ocorreu nos anos entre 2002-2005, onde três professoras se alternavam na autoria dos textos. A única excepcionalidade ficou registrada no ano de 2006, momento em que todas elas tiveram computada sua participação. Entretanto, a partir de 2007, o revezamento teve reincidência, seguido de oscilações na quantidade dos trabalhos divulgados ao público nos eventos dos quais participaram essas docentes.

No universo das professoras representadas na amostra estatística, a menor freqüência aos congressos na condição de autora de trabalho completo, deu-se com as docentes 
Elizabeth Teixeira e Rosa Mendonça de Brito. A primeira publicou 6 trabalhos em seis congressos, perfazendo um a cada evento; enquanto a segunda registrou em seu Currículo Lattes, tão-somente a participação em eventos nos anos de 2006 e de 2009, assegurando a publicação de 3 trabalhos, sendo 1 no início desse intervalo histórico e 2 ao final.

Embora os trabalhos completos representem a maior parcela da produção científica acumulada entre as docentes, houve casos em que esse tipo de veículo perde seu prestígio em face dos periódicos, livros e capítulos de livros, mas em outros, foi assumido como elemento central da prática de publicação dos resultados das pesquisas desenvolvidas.

\section{Temáticas investigativas contidas nos projetos de pesquisa}

Por último, as reflexões assentaram Sobre os objetos de estudos anunciados nas temáticas investigativas conduzidas por docentes do sexo feminino, momento em que foram examinados os títulos dos projetos de pesquisa coordenados pelas docentes.

$\mathrm{Na}$ investigação realizada por Ferreira $(2009$, p. 1) a respeito das tendências e perspectiva que marcam a pesquisa educacional no Brasil, houve o estudo das "tendências de pesquisa, compartilhadas no país nos últimos anos e as percepções destas tendências no contexto educacional". Para a autora, a atividade de pesquisa recebe a seguinte definição:

Uma abordagem sobre os contextos de pesquisa exige explicitar, antes, de qual pesquisa se fala, tendo em vista as diversas possibilidades de se entender esta prática. Entendo a pesquisa como uma ação intencional e metodologicamente estruturada na busca de uma resposta para uma pergunta previamente elaborada. Produzir pesquisa é ser criativo, reinventar a história e os fazeres humanos sob um olhar particular. Trata-se de uma atividade coletiva, cuja função primordial é atribuir sentidos ao cotidiano, revendo e significando identidades e histórias.

Para Ferreira (Op. Cit., p. 2-8) a pesquisa e a pesquisa educacional em solo brasileiro teriam passado por distintos períodos históricos: século XVIII - influenciados pelos trabalhos dos naturalistas, temos o movimento Realistas, Naturalistas e Impressionistas, preocupados em "explicar a relação homem/animal a partir de aspectos sociais"; início do século XX - outras tendências científicas chegam ao Brasil, nas áreas da biologia e da matemática, oriundas, sobretudo da França e da Inglaterra e Alemanha, que se caracterizava como um tipo de "pesquisa praticada por cientistas estrangeiros ou por brasileiros regressando de estudos fora do país"; década de 1930 - "amparados pela idéia de projeto como metodologia de aula", identificava-se "o gérmen da pesquisa em educação: quando os professores já não simplesmente reproduzem os fazeres, mas buscam, a partir de sua própria realidade, produzir planejamentos e inovar divulgada pelos escolanovistas, surge a primeira e incipiente idéia de pesquisa"; após o período das guerras mundiais (1945) - surgimento de "importantes instituições fomentadoras e de apoio à pesquisa científica, tais como CNPq, FAPESP, SBPC; década de 1960 - fase em que "consolidou-se o espaço de pós-graduação e ampliou-se significativamente a quantidade de cursos e instituições no país"; década de 1970-1980 - ocorre "maior desenvolvimento da pesquisa educacional no país, agora organizada, subsidiada e estimulada", além disso, "A propagação da metodologia de pesquisa-ação e da teoria do conflito (...), fazem mudar o perfil da pesquisa educacional, abrindo espaço a abordagens críticas, em uma perspectiva multi/inter/transdisciplinar e de tratamentos multidimensionais"; décadas de 1980 a 1990 - verificou-se que "o exame de situações 'reais' do cotidiano da escola e da sala de aula é que constituiu uma das principais preocupações dos pesquisadores, a partir da inversão também do lugar de onde olha o fenômeno, antes fora e agora dentro do próprio fenômeno". 
Com base na cronologia construída pela autora, verifica-se que passados 79 anos em que teve gênese a pesquisa educacional no Brasil, ainda existem dificuldades para o exercício dessa prática científica, tais como: escrever; a formulação da pergunta; a descrição metodológica; o referencial teórico; o financiamento da pesquisa que atribui seu foco na educação básica e o pouco caso em relação ao ensino superior; trabalhos de professores universitários que são publicados "unicamente para servir na obtenção de títulos"; "associação entre pesquisa e extensão, como meio de ampliar os ganhos da universidade"; isenção do Estado quanto à realização da pesquisa educacional, uma vez que esta "não garante lucros" (p. 50-51).

$\mathrm{Na}$ atualidade, a pesquisa educacional tem sido realizada sob duas perspectivas: "a pesquisa positivista e a pesquisa com base nas teorias críticas". A primeira tendência "admite, como fonte única de conhecimento e critério de verdade, a experiência, os fatos positivos, os dados sensíveis. A filosofia é reduzida à metodologia e à sistematização das ciências". A segunda "considera a realidade como um processo em movimento, em transformação. Nesta perspectiva, o investigador e o que é investigado estão em diálogo, comunicando-se, em um processo de cooperação e de contradições, através do método dialético" (p.51-52).

Há um reconhecimento por parte da autora de que "a pesquisa educacional avançou muito nos últimos anos". Todavia, é preciso alcançar novos propósitos, como aqueles referentes a: "uma concepção de ciência que alie os fenômenos educacionais e a pesquisa"; "uma opção teórico-metodológica efetivamente embasada nos referenciais teóricos dos professores-pesquisadores"; "uma avaliação e divulgação de resultados das pesquisas" (p.52-53).

No período compreendido entre os anos de 1989-2011, as docentes se envolveram na coordenação e participação em projetos de pesquisa que exploraram temáticas diversas. Chama atenção o fato de que mesmo antes de se formar pesquisadoras, algumas delas já se aventuraram pela prática científica. Houve situações em que as professoras com titulação anterior ao intervalo histórico somente se engajaram na autoria e coordenação de projetos posteriormente à passagem pela pós-graduação stricto sensu. Contudo, à medida que obtiveram os respectivos títulos de mestrado e doutorado, e com a constituição dos respectivos grupos de pesquisa, ampliou-se consideravelmente a inserção na atividade investigativa.

Foi no contexto de conflito entre as tendências da pesquisa educacional que marcaram as décadas de 1980-1990, ou seja, positivismo e dialética, que as pesquisadoras passaram a comprometer parte de sua carga de trabalho docente com a coordenação dos projetos de pesquisa.

Ao longo desse período, as pesquisadoras conduziram investigações com temáticas diversas perfazendo um total de 46 projetos. Dessa quantidade 13 foram coordenados por Rosa Mendonça de Brito (28,26\%); outros 11 estiveram sob a direção de Olgaíses Cabral Maués (23,91\%); Tânia Suely Azevedo Brasileiro atingiu 4 (8,69\%); e Elizabeth Teixeira alcançou a maior inserção computando 18 (39,13\%).

A temática de pesquisa saberes surge associada à formação, imaginário, representações, cuidar em saúde, educação popular e prática pedagógica, e foi aquela que incidiu nos estudos das professoras Rosa Mendonça de Brito, Tânia Suely Azevedo Brasileiro e Elizabeth Teixeira.

O pensamento e práticas educativas docentes também alcançaram grande repercussão entre os objetos de estudo eleitos entre 50\% das pesquisadoras, dentre elas estão Tânia Suely Azevedo Brasileiro e Elizabeth Teixeira.

QUADRO Nº 02: Distribuição dos Projetos de Pesquisa pelos Docentes 


\begin{tabular}{|c|c|}
\hline $\begin{array}{l}\text { Rosa } \\
\text { Mendonça de } \\
\text { Brito }\end{array}$ & $\begin{array}{l}\text { 2011 - 2012: Saber local e a formação de professores na faculdade de educação da universidade federal do } \\
\text { amazonas - UFAM } \\
\text { 2011 - 2012: Saber Local: Tempo de reencontro do homem com a razão sensível. } \\
\text { 2009 - 2011: O processo Educativo em Manaus e as Instituições Educativas Católicas. } \\
\text { 2009 - 2011: História da Faculdade de Educação da Universidade Federal do Amazonas - UFAM. } \\
\text { 2009 - 2010: } 100 \text { ANOS UFAM - } 2^{\mathrm{a}} \text { ED. REVISTA E AMPLIADA. } \\
\text { 2007 - 2009: } 100 \text { Anos de Universidade Federal do Amazonas. } \\
\text { 2005 - 2006: História da Faculdade de Educação da Universidade Federal do Amazonas - UFAM. } \\
\text { 2004 - 2006: Identidades Amazônicas: meio ambiente e educação. } \\
\text { 2003 - 2004: Da Universidade Livre de Manaus à Universidade Federal do Amazonas. } \\
\text { 2000 - 2007: Levantamento de dados sobre a História da educação nos colégios religiosos católicos de Manaus. } \\
\text { 2000 - 2006: A resignificação da razão sensível no processo de construção do conhecimento na Universidade } \\
\text { Federal do Amazonas. } \\
\text { 2000 - 2001: Trajetória do Programa de Pós-Graduação em Educação da Universidade do Amazonas. } \\
\text { 1998 - 2005: Identidades Étnicas e Culturais da Amazônia: Ser, Pensar, Sentir e Fazer. }\end{array}$ \\
\hline $\begin{array}{l}\text { Olgaíses } \\
\text { Cabral Maués }\end{array}$ & $\begin{array}{l}\text { 2010 - 2013: Trabalho Docente na Educação Básica no Estado do Pará } \\
\text { 2009 - 2013: Organização Institucional e Acadêmica na Expansão da Educação Superior no Brasil. } \\
\text { 2009 - 2012: Projeto do Programa Nacional de Cooperação Acadêmica- Ação Novas Fronteiras- PROCAD, } \\
\text { Observatório de Trabalho Docente. } \\
\text { 2008 - 2010: As Políticas de Avaliação da Educação Superior e os Impactos sobre o Trabalho Docente. } \\
\text { 2008 - 2010: Projeto Integrado de Grupos de Pesquisa Observatório de Trabalho Docente. } \\
\text { 2007 - 2009: As políticas de educação superior, o trabalho docente e a cultura acadêmica: as possíveis relações. } \\
\text { 2006 - 2007: Análise do Censo da Educação Superior no Brasil } 1991-2004 \text {. } \\
\text { 2005 - 2007: As Políticas de Educação Superior e os Impactos sobre o Trabalho Docente. } \\
\text { 2004 - 2005: O Projeto Político Pedagógico do Curso de Pedagogia da UFPA. As concepções de profissional da } \\
\text { educação. } \\
\text { 2003 - 2006: A Produção Científica sobre Educação Superior no Brasil: } 1968-2000 \text {. } \\
\mathbf{2 0 0 2 ~ - ~ 2 0 0 4 : ~ A s ~ M u t a c ̧ o ̃ e s ~ n o ~ M u n d o ~ d o ~ T r a b a l h o ~ e ~ a s ~ P o l i ́ t i c a s ~ d e ~ F o r m a c ̧ a ̃ o ~ d o s ~ P r o f i s s i o n a i s ~ d a ~ E d u c a c ̧ a ̃ o . ~}\end{array}$ \\
\hline $\begin{array}{l}\text { Tânia Suely } \\
\text { Azevedo } \\
\text { Brasileiro }\end{array}$ & $\begin{array}{l}\text { 2008 - 2010: Saberes, reflexões e práticas pedagógicas docentes na UNIR: possibilidades e limites na } \\
\text { transformação da práxis no ensino da Matemática } \\
\text { 2008 - Atual: Pensamento docente e prática pedagógica universitária concepções teóricas e perspectivas } \\
\text { metodológicas na formação do Psicólogo Escolar. } \\
\text { 2004 - Atual: Pensamento Docente e Prática Pedagógica Universitária - Reflexões teóricas e perspectiva } \\
\text { metodológica. } \\
\text { 2002 - Atual: Paulo Freire revisitado por autores estrangeiros e brasileiros }\end{array}$ \\
\hline & $\begin{array}{l}\text { 2010 - Atual: Laboratório de tecnologias educativas: Estudo I - Interlocução, produção e validação de materiais } \\
\text { educativos para subsidiar o agir educativo-cuidativo em enfermagem. } \\
2009 \text { - Atual: Observatório de práticas educativas em saúde-doença: estudo exploratório I. } \\
2009 \text { - Atual: Membro da Equipe: As transformaçães do cuidado de saúde e enfermagem em tempos de aids. } \\
2008 \text { - 2010: Membro da Equipe: Lágrimas da Amazônia: vidas de vítimas de Escalpelamento. } \\
2008 \text { - 2009: Praxis revelada entre educadores e educandos de comunidades hospitalares de Belém. } \\
\text { 2007 - 2009: Percepção entre mulheres e agentes indígenas de saúde a respeito de DST e HIV/AIDS: pesquisa-ação } \\
\text { com vistas a qualificação da informação e educação em saúde. } \\
\text { 2007 - 2009: Travessias na Educação de Adultos: Saberes do Cuidar na Práxis Alfabetizadora do NEP/CCSE em } \\
\text { Comunidades Hospitalares. (Edital Universal MCT/CNPq No15/2007). } \\
2005 \text { - 2006: Travessias de saberes na educação popular: avaliação das repercussões do programa quartas saudáveis } \\
\text { no cotidiano das mulheres da ilha de caratateua. } \\
2005 \text { - 2006: Membro da Equipe. Cartografia dos saberes: representações de alfabetizandos de São Domingos do } \\
\text { Capim. } \\
\text { 2003 - 2006: Cartografias Ribeirinhas: saberes/fazeres/dizeres sobre o cuidar da saúde de si e da família entre } \\
\text { mulheres da ilha. } \\
2003 \text { - 2006: Dinâmica Entre Nós: uma tecnologia sócio-educativa em construção. } \\
2003 \text { - 2004: Saberes, imaginários e representações sociais cotidianas de jovens e adultos das comunidades } \\
\text { ribeirinhas do município de São Domingos do Capim. } \\
2001 \text { - 2003: Pelo Indivíduo, Pelo Ambiente - PIPA II. } \\
1998 \text { - 2000: Pelo Indivíduo, Pelo Ambiente - PIPA I. } \\
1994 \text { - 1995: Formação do Enfermeiro para o Terceiro Milênio. } \\
1993 \text { - 1995: Etnoenfermagem. } \\
1993 \text { - 1994: Estratégias alternativas para o ensino de saúde na educação básica. } \\
1989 \text { - 1989: Interação em Enfermagem: importância da comunicação. }\end{array}$ \\
\hline
\end{tabular}

A educação superior e a produção científica do conhecimento ocuparam os trabalhos de pesquisa das professoras Rosa Mendonça de Brito e Olgaíses Cabral Maués. A primeira delas também acentuou seus estudos sobre identidades e história da educação; enquanto a segunda priorizou as políticas de educação superior e o trabalho docente.

Elizabeth Teixeira foi a única pesquisadora a explorar os temas relacionados às tecnologias educacionais, as vítimas de escalpelamento, o cuidado de saúde e enfermagem, a informação e educação em saúde, educação de adultos, o indivíduo e ambiente, comunicação, ensino de saúde, e a etnoenfermagem.

Embora tenham ocorrido coincidências em parte das temáticas configuradoras dos projetos desenvolvidos pelas pesquisadoras em educação, essa escolha está associada ao 
interesse de cada docente em relação aos assuntos abordados, como também devido às finalidades estabelecidas para os grupos de pesquisa em que são germinadas. Por outro lado, as agências de fomento igualmente exercem interferências por meio do financiamento da pesquisa educacional que induz à perquirição de certos acontecimentos históricos ligados à área de educação.

\section{CONSIDERAÇÕES FINAIS}

A concretização deste estudo permitiu aprofundar a compreensão acerca das trajetórias de escolarização e do trabalho doente das mulheres que se tornaram pesquisadoras no campo da educação na Amazônia, particularmente a formação acadêmica, o vínculo com os grupos de pesquisa, os temas que permeiam os objetos das suas investigações, bem como os veículos por onde circulam seus produtos científicos.

No aspecto relacionado à titulação, as pesquisadoras possuem perfis acadêmicos semelhantes quando a ênfase recai no ensino de graduação, mestrado e doutorado. Contudo, raras foram as que cursaram especialização e o estágio pós-doutoral. Além disso, aquelas vinculadas a Programas de Pós-Graduação em Educação são originárias de áreas de concentração diferentes, havendo poucas delas que desde a graduação firmou seus passos no campo da educação.

$\mathrm{O}$ aparecimento dos grupos de pesquisa fez com que as docentes se organizassem em torno de equipes de trabalho reunindo pesquisadores e estudantes, com efeito no fomento da pesquisa, na organização do espaço institucional, na produção de conhecimento científico na área de educação, bem como o acesso a recursos financeiros, e o intercâmbio acadêmicocientífico interinstitucional. Convém ressaltar seus efeitos no incremento da política de Iniciação Científica, na produção de dissertações de mestrado e teses de doutorado, e na ampliação da produção bibliográfica consolidada nos artigos divulgados em periódicos, livros, e capítulos de livros.

Por meio do exame da trajetória de produção científica das pesquisadoras da área de educação, ficou evidenciado que elas têm perfis bibliométricos distintos, uma vez que os trabalhos completos obtiveram a maior fração da produção, embora em algumas situações esse tipo de veículo tenha ficado com menor participação quando comparado aos periódicos, livros e capítulos de livros.

Deve-se destacar que a conquista dos títulos de mestrado e doutorado repercutiu na criação dos grupos de pesquisa, como também produziu efeitos na atividade investigativa das pesquisadoras, que a partir das décadas de 1980-1990, assumiram a coordenação de diversos projetos de pesquisa.

\section{Referências}

ALVES, Wanderson Ferreira; CUNHA, Daisy Moreira. Da atividade humana entre paideia e politeia: saberes, valores e trabalho docente. Disponível em:

http://34reuniao.anped.org.br/images/trabalhos/GT08/GT08-217\%20res.pdf

ASSOCIAÇÃO NACIONAL DE PÓS-GRADUAÇÃO E PESQUISA EM EDUCAÇÃO. http://www.anped.org.br

BRASILEIRO, Tânia Suely Azevedo. Endereço para acessar este CV:

http://lattes.cnpq.br/7125374751055075. Última atualização do currículo em 27/12/2011

BRITO, Rosa Mendonça de. Endereço para acessar este CV:

http://lattes.cnpq.br/7467942519181644. Última atualização do currículo em 04/10/2011

CAMPOS, Vanessa Therezinha Bueno. Docência no ensino superior brasileiro:

representações de pós-graduandos de instituições federais de ensino superior. Disponível em: http://34reuniao.anped.org.br/images/trabalhos/GT11/GT11-1133\%20res.pdf 
CONSELHO NACIONAL DE DESENVOLVIMENTO CIENTÍFICO TECNOLÓGICO. http://www.cnpq.br

COSTA JUNIOR, Wercy Rodrigues. Política de avaliação da pós-graduação e suas conseqüências no trabalho dos professores-pesquisadores. Disponível em: http://34reuniao.anped.org.br/images/trabalhos/GT08/GT08-217\%20res.pdf FUNDAÇÃO COORDENAÇÃO DE APERFEIÇOAMENTO DE PESSOAL DE NÍVEL SUPERIOR. Síntese de Indicadores. http://www.capes.gov.br

ISAIA, Silvia Maria de Aguiar; MACIEL, Adriana Moreira da Rocha; BOLZAN, Doris Pires Vargas. Educação superior: a entrada na docência universitária. Disponível em: http://www.anped.org.br/33encontro/app/webroot/files/file/Trabalhos\%20em\%20PDF/GT0 8-6411--Int.pdf

MACIEL, Adriana Moreira da Rocha; ISAIA, Silvia Maria de Aguiar; BOLZAN, Doris Pires Vargas. Trajetórias formativas de professores universitários: Repercussões da ambiência no desenvolvimento profissional docente. Disponível em: http://www.anped.org.br/reunioes/32ra/arquivos/trabalhos/GT08-5457--Int.pdf MAUÉS, Olgaíses Cabral. Endereço para acessar este CV: http://lattes.cnpq.br/0118802077232494. Última atualização do currículo em 15/12/2011 MURY, Rita de Cassia Ximenes. Profissionalização docente: da aderência à vocação. Disponível em: http://34reuniao.anped.org.br/images/trabalhos/GT08/GT08-520\%20res.pdf OLIVEIRA, Valeska Maria Fortes de. Docência universitária e o ensino superior: análise de uma experiência formadora. Disponível em: http://34reuniao.anped.org.br/images/trabalhos/GT08/GT08-608\%20res.pdf POWACZUK, Ana Carla Hollweg; BOLZAN, Doris Pires Vargas. Atividades de produção da docência: a professoralidade universitaria. Disponível em: http://34reuniao.anped.org.br/images/trabalhos/GT08/GT08-809\%20res.pdf

ROSA, Maria Inês Petrucci. Formação docente em disciplinas escolares: memórias e identidades no contexto da cultura da escola. Disponível em:

http://34reuniao.anped.org.br/images/trabalhos/GT12/GT12-327\%20res.pdf

TEIXEIRA, Elizabeth. Endereço para acessar este CV:

http://lattes.cnpq.br/6939587645193038. Última atualização do currículo em 03/01/2012

FERREIRA, Lílian Soares. Pesquisa educacional no Brasil: tendências e perspectivas. CONTRAPONTOS - Volume 9 n $^{\circ} 1$ - pp. 43-54 - Itajaí, jan/abr 2009

http://www6.univali.br/seer/index.php/rc/article/view/974/831

Notas

${ }^{1}$ O Termo de Adesão e de Condições de Uso Sistema de Currículos da Plataforma Lattes, destaca que o compartilhamento das informações do Currículo disponibilizado na Plataforma Lattes http://www.cnpq.br assume caráter público, por essa razão, manteve-se os nomes dos sujeitos na composição dos indicadores expressos nos quadros, tabelas e gráficos, bem como nas análises realizadas no transcurso do texto.

2 Jornal da Universidade Federal do Pará. Edição 81, março http://www.ufpa.br/beiradorio/novo/index.php/2010/111-edicao-81-marco/1005--grupos-fortaleceminvestigacao-cientifica. Acesso em: 06/10/2011.

${ }^{3}$ Universidade Federal do Pará. Pró-Reitoria de Planejamento e Desenvolvimento. Diretoria de Informações Institucionais. Anuário Estatístico 2011 - Ano Base 2010 / UFPA PROPLAN Diretoria de Informações Institucionais. Belém: A Diretoria, 2011.p. 16 <http://www.proplan.ufpa.br/doc/Anuario2011_AB2010.pdf> Acesso em 08.10.2011

Recebido em novembro/2012

Aprovado em dezembro/2012 